\title{
B2-Adrenergic receptor activation on donor cells ameliorates acute GvHD
}

\author{
Hemn Mohammadpour, ${ }^{1}$ Joseph L. Sarow, ${ }^{1}$ Cameron R. MacDonald, ${ }^{1}$ George L. Chen, ${ }^{2}$ Jingxin Qiu, ${ }^{3}$ \\ Umesh C. Sharma, ${ }^{4}$ Xuefang Cao, ${ }^{5}$ Megan M. Herr, ${ }^{2}$ Theresa E. Hahn, ${ }^{2}$ Bruce R. Blazar, ${ }^{6}$ \\ Elizabeth A. Repasky, ${ }^{1}$ and Philip L. McCarthy ${ }^{2}$ \\ ${ }^{1}$ Departments of Immunology, ${ }^{2}$ Medicine, Transplant and Cellular Therapy Program, and ${ }^{3}$ Pathology, Roswell Park \\ Comprehensive Cancer Center, Buffalo, New York, USA. ${ }^{4}$ Department of Medicine, Jacobs School of Medicine \& Biomedical \\ Sciences, Buffalo, New York, USA. ${ }^{5}$ Department of Microbiology and Immunology, Marlene and Stewart Greenebaum \\ Comprehensive Cancer Center, University of Maryland, Baltimore, Maryland, USA. ${ }^{6}$ Department of Pediatrics, Division of \\ Blood and Marrow Transplantation, University of Minnesota, Minneapolis, Minnesota, USA.
}

Acute graft versus host disease (aGvHD) remains a major impediment to successful allogeneic hematopoietic cell transplantation (allo-HCT). To solve this problem, a greater knowledge of factors that regulate the differentiation of donor $T$ cells toward cytotoxic cells or Tregs is necessary. We report that the $\beta 2$-adrenergic receptor ( $\beta 2-A R$ ) is critical for regulating this differentiation and that its manipulation can control aGvHD without impairing the graft-versus-tumor (GvT) effect. Donor T cell $\beta 2-A R$ expression and signaling is associated with decreased aGvHD when compared with recipients of $\beta 2-A R^{-/-}$donor $T$ cells. We determined that $\beta 2-A R$ activation skewed $C D 4^{+} T$ cell differentiation in vitro and in vivo toward Tregs rather than the Thelper 1 (Th1) phenotype. Treatment of allo-HCT recipients with a selective $\beta 2$-agonist (bambuterol) ameliorated aGvHD severity. This was associated with increased Tregs, decreased cytotoxic T cells, and increased donor BM-derived myeloid-derived suppressor cells (MDSCs) in allogeneic and humanized xenogeneic aGvHD models. $\beta 2-A R$ signaling resulted in increased Treg generation through glycogen synthase kinase-3 activation. Bambuterol preserved the GvT effect by inducing NKC2D+ effector cells and central memory T cells. These data reveal how $\beta$-AR signaling can be targeted to ameliorate GvHD severity while preserving GvT effect.

Conflict of interest: PM has received honoraria from and participated in advisory boards related to multiple myeloma treatment from Bristol Myers Squibb, Bluebird, Celgene, Janssen, Juno Karyopharm, and Takeda.

Copyright: (ㄷ) 2020, American Society for Clinical Investigation.

Submitted: March 5, 2020

Accepted: May 13, 2020

Published: June 18, 2020

Reference information: /CI Insight. 2020;5(12):e137788.

https://doi.org/10.1172/jci. insight.137788.

\section{Introduction}

Allogeneic hematopoietic cell transplant (allo-HCT) is a potentially curative intervention for patients with hematological malignancies due to eradication of host malignant cells by donor $\mathrm{T}$ cells (the graft-versus-tumor; GvT) effect. Donor T cells may attack healthy tissues, typically skin, gastrointestinal (GI) tract, and liver, leading to graft-versus-host disease (GvHD). Acute or chronic GvHD can develop in $40 \%-60 \%$ of patients, with a mortality rate of about $20 \%(1-4)$. GvHD can be prevented or reduced by depleting donor $\mathrm{T}$ cells, but this can result in increased relapse (5). There is a continued need to understand how to decrease acute GvHD (aGvHD) severity and mortality. In this study, we focused on studying the potentially novel effect of $\beta 2$-adrenergic receptor ( $\beta 2$-AR) signaling on immune regulatory pathways during preclinical allo-HCT, with the goal of mitigating aGvHD while preserving the GvT effect.

During aGvHD, distinct $\mathrm{T}$ cell subsets develop from naive T cells, including T helper 1 (Th1), Th17, and Tregs $(6,7)$. Th1/Th17 cytotoxic T cells can mediate tissue damage, especially in the liver and GI tract $(4,8$, 9). Th1 cells are critical for aGvHD pathology through the release of IFN- $\gamma$, although IFN- $\gamma$ has been reported to be both detrimental and beneficial with tissue-dependent effects (10). IL-17A-producing Th17 cells cause aGvHD immunopathology during $\mathrm{CD}^{+} \mathrm{T}$ cell-mediated inflammation (11). However, cutaneous aGvHD is associated with expansion of tissue-localized Th1, not Th17 cells (12), and T cell ROR $\gamma \mathrm{t}$ expression (Th17 transcription factor) exacerbates aGvHD $(13,14)$. Tregs ameliorate aGvHD severity $(15-18)$, critical to the control of the immunopathology mediated by inflammatory T cells (19). There is an imbalance in inflammatory $\mathrm{T}$ cells and Tregs in aGvHD target organs $(18,20)$.

We previously demonstrated, in a model of adrenergic stress, that housing recipient allo-HCT mice in standard ambient temperatures (ST) (21) resulted in decreased aGvHD compared with mice housed at 
warmer, thermoneutral temperature (TT). Housing mice at TT substantially reduces norepinephrine and $\beta$-AR signaling on immune cells (22). Treatment of allo-HCT mice housed at ST with the pan-beta blocker propranolol increased aGvHD severity, indicating that $\beta$-AR signaling is protective against aGvHD (22). Furthermore, we demonstrated that blockade of recipient $\beta 2$-ARs enhanced the GvT effect by modulating antigen presenting cells (23). It was critical to continue to define the role of T cell $\beta 2$-AR signaling, especially $\mathrm{CD} 4^{+} \mathrm{T}$ cell differentiation. In addition, the detailed mechanisms of $\beta 2$-AR signaling and its downstream effects on immunomodulation after allo-HCT remained incompletely understood.

Adrenergic receptors (ARs) are G protein-coupled receptors, classified into 2 general classes: $\alpha$-ARs and $\beta$-ARs. The $\alpha 1$-AR is primarily expressed on endothelial cells, and the $\alpha 2-\mathrm{AR}$ is more ubiquitously expressed. $\beta 1$-ARs and $\beta 3$-ARs are primarily expressed in cardiac and adipose tissues, respectively, while $\beta 2$-ARs are extensively distributed especially in the respiratory tract $(24,25)$ and on immune cells $(26$, 27). Emerging studies reinforce an inhibitory role of $\beta 2$-AR signaling on $\mathrm{T}$ cell function, especially $\mathrm{CD} 8^{+}$ $\mathrm{T}$ cells, in preclinical and clinical tumor models $(27,28)$. The $\beta 2-\mathrm{AR}$ is activated by catecholamines (norepinephrine and epinephrine), released by the sympathetic nervous system $(27,29)$ and splenic tyrosine hydroxylase-expressing cells (30). This $\beta 2-\mathrm{AR}-$ mediated regulation affects $\mathrm{T}$ cell antitumor functions (28), DC antigen presentation (23), B cell expression of costimulatory molecules $(31,32)$, and myeloid-derived suppressor cell (MDSC) immunosuppression (26).

Thus, we focused on the role of $\beta 2$-AR signaling on immune cell development and pathways during aGvHD. We asked whether $\beta 2$-AR expression by allogeneic donor T cells modulates aGvHD pathology and how this modulation occurs. Using major histocompatibility complex (MHC) and minor histocompatibility antigen (miHA) mismatched HCT murine models, and a humanized NOD-scid IL-2R $\gamma^{-1-}$ (NSG) model of aGvHD, we demonstrate that $\beta 2$-AR expression by allogeneic $\mathrm{T}$ cells regulates the differentiation of $\mathrm{CD}^{+} \mathrm{T}$ cells from Th1/Th17 to a Th2/Treg phenotype, ameliorating aGvHD without compromising GvT. These data lead us to propose that selective $\beta 2$-AR agonists may serve as potential therapeutic agents to attenuate aGvHD while preserving the GvT effect.

\section{Results}

$\beta 2-A R$ s expressed by allogeneic donor T cells ameliorate aGvHD after allo-HCT. Our previous work demonstrated that housing mice at ST decreased aGvHD symptoms compared with housing mice at TT (22). This suggested that $\beta$-AR signaling is important in $\mathrm{GGvHD}$, but how this signaling modulates the allogenic $\mathrm{T}$ cell response after allo-HCT is not well characterized.

To understand the contribution of $\beta 2$-AR signaling during donor $\mathrm{T}$ cell-mediated aGvHD, we used models of MHC and miHA-mismatched HCT. WT BALB/c mice $\left(\mathrm{H}-2 \mathrm{k}^{\mathrm{d}}\right)$ were lethally irradiated and given T cell-depleted BM (TCD-BM) from CD45.2+ WT C57BL/6 (B6) mice $\left(\mathrm{H}-2 \mathrm{k}^{\mathrm{b}}\right)$, with or without B6 $\mathrm{T}$ cells to induce aGvHD. Donor T cells from spleen and liver obtained at day 14 after allo-HCT were analyzed for $\beta 2-\mathrm{AR}$ expression by flow cytometry. Donor $\mathrm{CD} 4^{+}$and $\mathrm{CD} 8^{+} \mathrm{T}$ cells significantly increased the expression of $\beta 2$-ARs in allo-HCT recipients, 14 days after transplant in spleen and liver; however, expression on resting naive T cells was low (Figure 1A and Supplemental Figure 1A; supplemental material available online with this article; https://doi.org/10.1172/jci.insight.137788DS1). To better understand how $\beta 2$-AR signaling modulates the severity of aGvHD, lethally irradiated BALB/c $\left(\mathrm{H}-2 \mathrm{k}^{\mathrm{d}}\right)$ and C3H/SW $\left(\mathrm{H}-2 \mathrm{k}^{\mathrm{b}}\right)$ mice were given TCD-BM with or without $\mathrm{B} 6 \mathrm{WT}$ or $\beta 2-\mathrm{AR}^{-/-} \mathrm{T}$ cells. $\beta 2-\mathrm{AR}^{-/-} \mathrm{T}$ cells induced more severe aGvHD than WT T cells, as manifested by greater weight loss and decreased survival in major mismatch $(\mathrm{B} 6 \rightarrow \mathrm{BALB} / \mathrm{c})$ (Figure $1 \mathrm{~B})$ and miHA mismatch $(\mathrm{B} 6 \rightarrow \mathrm{C} 3 \mathrm{H} / \mathrm{SW})($ Figure $1 \mathrm{C})$ transplants. To separate the $\beta 2-\mathrm{AR}$ effects on $\mathrm{CD}^{+}$and $\mathrm{CD} 8^{+} \mathrm{T}$ cells during $\mathrm{GGvHD}$, recipient $\mathrm{BALB} / \mathrm{c}$ mice were injected with TCD-BM with or without $\mathrm{CD}^{+} \mathrm{T}$ cells from WT or $\beta 2-\mathrm{AR}^{-/-}$mice. As compared with WT CD4 ${ }^{+} \mathrm{T}$ cells, $\beta 2-\mathrm{AR}^{-/-} \mathrm{CD} 4^{+} \mathrm{T}$ cells significantly increased weight loss and mortality in BALB/c recipients (Figure 1D). In all models, weight loss and diarrhea were the most prominent phenotype, especially in recipients transplanted with $\beta 2-\mathrm{AR}^{-1-} \mathrm{T}$ cells. Histologic preparations of the small and large intestine were examined to assess aGvHD pathology in a blinded fashion. $\beta 2-\mathrm{AR}^{-1-} \mathrm{T}$ cells significantly increased the aGvHD score in small and large intestine compared with WT T cells (Supplemental Figure 2). These data suggest that $\beta 2$-AR expression on $\mathrm{T}$ cells, especially $\mathrm{CD} 4^{+} \mathrm{T}$ cells, reduces aGvHD lethality.

$T$ cell $\beta 2-A R$ expression alters $C D 4^{+} T$ cell differentiation after $M H C$-mismatched $H C T$. We next sought to investigate the mechanisms driving the suppressive function of $\beta 2$-AR signaling in $\mathrm{T}$ cells. Lethally irradiated $\mathrm{BALB} / \mathrm{c}$ recipients were transplanted with TCD-BM and $\mathrm{T}$ cells from $\mathrm{B} 6 \mathrm{WT}$ or $\beta 2-\mathrm{AR}^{-/}$donor mice. 
A Spleen Liver
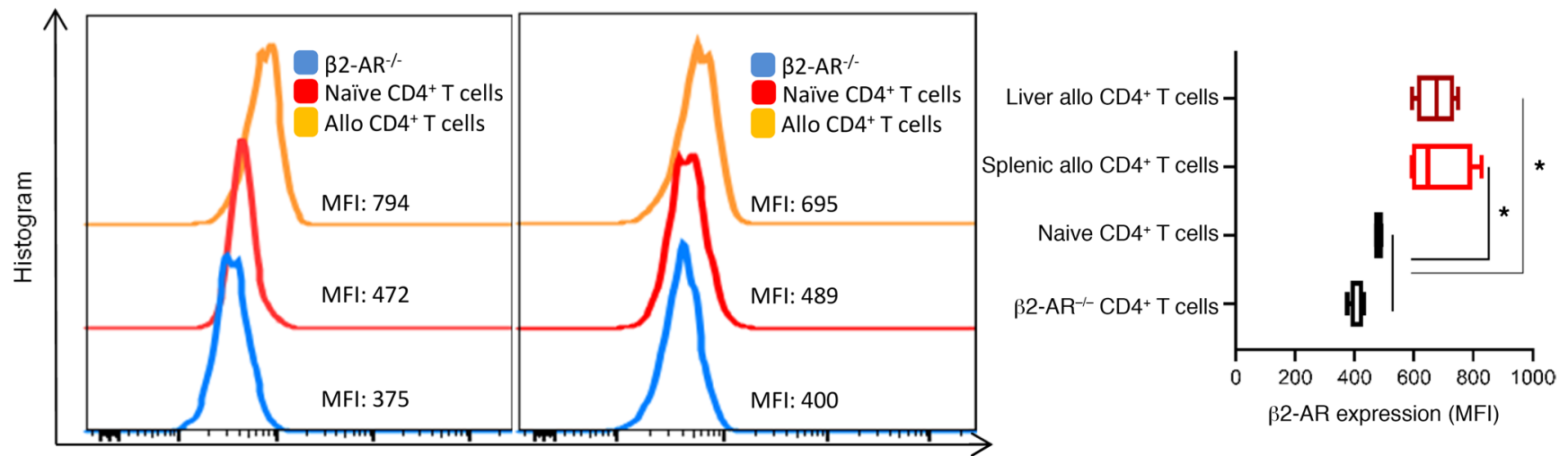

B2-AR
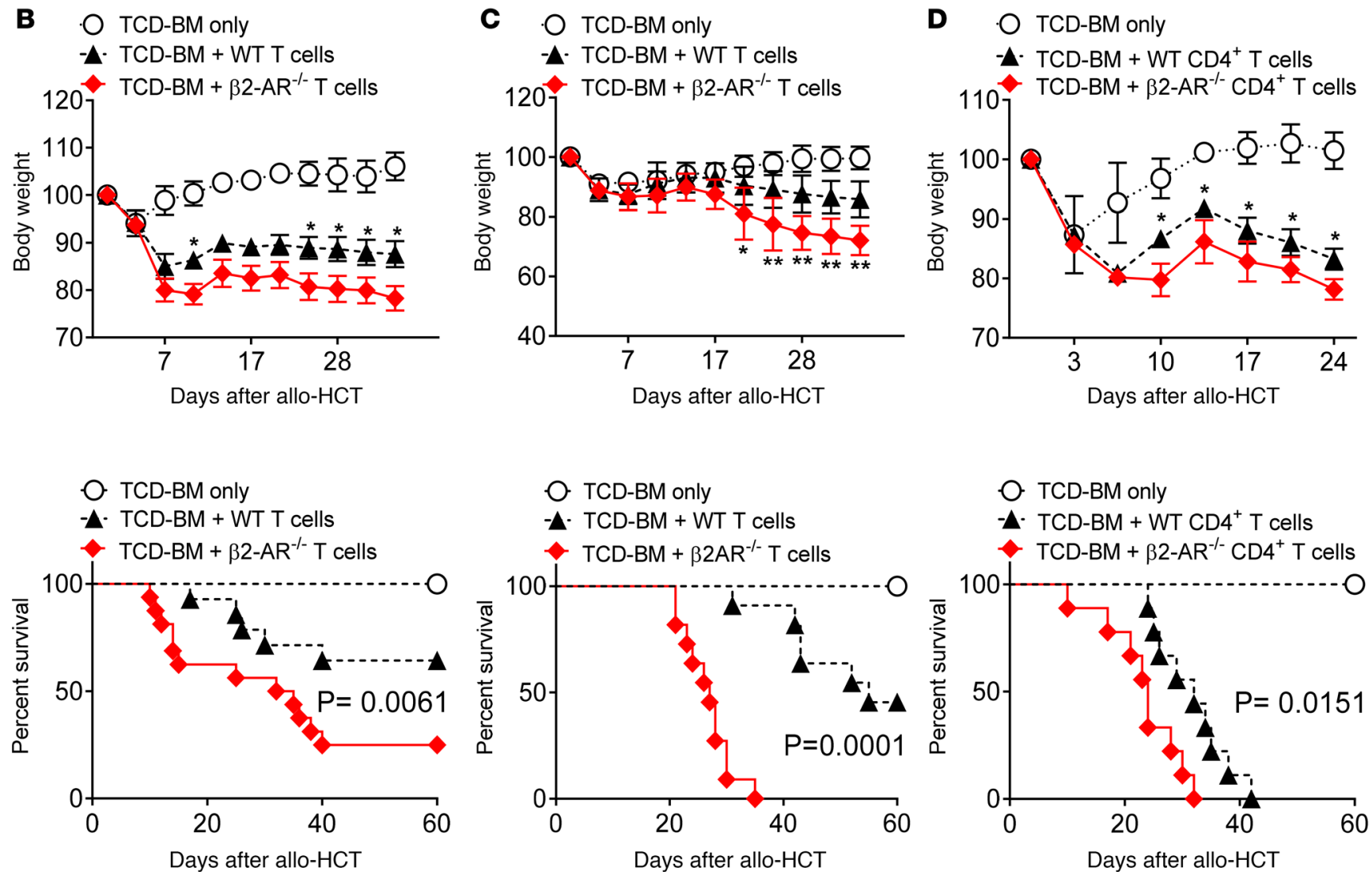

Figure 1. Expression of $\beta 2$-ARs on $T$ cells controls the severity and fatality of acute GvHD after allo-HCT. (A) $\beta 2-A R$ expression in $W T$ or $\beta 2-A R^{-/-}$CD $4^{+}$T cells harvested from spleen and liver on day 14 after allogenic T cell infusion. $\mathrm{CD} 4^{+} \mathrm{T}$ cells were gated from single live $\mathrm{H}-2^{\mathrm{b}+} \mathrm{H}-2^{\mathrm{d}-}-\mathrm{CD} 45^{+} \mathrm{CD} 3^{+}$cells, demonstrating an increase in $\beta 2$-AR expression in the allo CD4+ $\mathrm{T}$ cells. All recipients received $3.5 \times 10^{6} \mathrm{WT}$ C57BL/6 TCD-BM with or without T cells. (B) Body weight and survival of lethally irradiated BALB/c mice after allo-HCT BM alone or with $0.7 \times 10^{6} \mathrm{WT} C 57 \mathrm{BL} / 6$ or $\beta 2-\mathrm{AR}^{-1-}$ pan-T cells. (C) Body weight and survival of lethally irradiated $\mathrm{C} 3 \mathrm{H} / \mathrm{SW}$ mice after allo-HCT with BM alone or with $1.5 \times 10^{6} \mathrm{WT}$ C57BL/6 or $\beta 2-\mathrm{AR}^{-/-}$pan-T cells. (D) Body weight and survival of lethally irradiated BALB/c mice after allo-HCT with BM alone or with $0.2 \times 10^{6} \mathrm{WT} C 57 \mathrm{BL} / 6$ or $\beta 2-\mathrm{AR}^{-1-} \mathrm{CD} 4^{+}$T cells. All experiments demonstrated increased GvHD severity and mortality in the absence of the $\beta 2$-AR on T cells. Data pooled from 2 individual experiments, each with $n=6-8$ per group to obtain total of $n=12-16$ per group in B-D. For comparison of survival curves, a log-rank (Mantel-Cox) test was used in B-D. Two-way ANOVA with Tukey's multiple comparisons test was used for body weight difference in $\mathbf{B}-\mathbf{D} .{ }^{*} P<0.05,{ }^{*} P<0.01$. Body weight and survival data are shown as means \pm SEM. Other data are presented as median \pm min to max.

WT or $\beta 2-\mathrm{AR}^{-/-}$donor $\mathrm{CD}^{+}$and $\mathrm{CD}^{+} \mathrm{T}$ cells from day 14 splenocytes were isolated. Immune-related gene expression analyzed by mRNA microarray (nCounter Immunology Panel, NanoString) showed that $\beta 2-\mathrm{AR}^{-/-} \mathrm{CD}^{+} \mathrm{T}$ cells express more Th1-related genes, including Tbx21, Irf8, Eomes, and Ifng, while WT $\mathrm{CD}^{+} \mathrm{T}$ cells express more Th2- and Treg-associated genes, including Foxp3, Socs3, TGF 32 , Il10, Ptgs5, and 
Gata3 (Figure 2A). We also analyzed the gene expression of $\beta 2-\mathrm{AR}^{-/-}$and $\mathrm{WT} \mathrm{CD} 8^{+} \mathrm{T}$ cells on day 14 after allo-HCT. $\beta 2-\mathrm{AR}^{-1-} \mathrm{CD} 8^{+} \mathrm{T}$ cells express more cytotoxic genes, including Il17b, Tfrc, Icos, Tbx21, and Csf2, with decreased expression of immunosuppressive genes, including Il10, TgfB3, and Foxp3 (Supplemental Figure $1 \mathrm{~B})$, confirming previous studies $(28,33)$. These data demonstrate that $\beta 2$-AR signaling also suppresses the cytotoxic function of $\mathrm{CD}^{+} \mathrm{T}$ cells.

To assess inflammatory cytokine production by $\beta 2-\mathrm{AR}^{-/-} \mathrm{CD} 4^{+}$and $\mathrm{CD} 8^{+} \mathrm{T}$ cells, lethally irradiated BALB/c recipients were transplanted with $\mathrm{B} 6 \mathrm{TCD}-\mathrm{BM}$ and $\mathrm{WT}$ or $\beta 2-\mathrm{AR}^{-1-} \mathrm{T}$ cells. Donor $\mathrm{T}$ cells were isolated from spleen and liver on days 7 and 14 and examined for transcription factor and cytokine expression levels. The increased percentages of $\mathrm{CD} 4^{+} \mathrm{T}_{-} \mathrm{bet}^{+}, \mathrm{CD} 4^{+} \mathrm{IFN}-\gamma^{+}, \mathrm{CD} 4^{+} \mathrm{IL}-17^{+}$, and $\mathrm{CD}^{+} \mathrm{T}$-bet ${ }^{+}$Roryt $\mathrm{t}^{+}$in $\beta 2-\mathrm{AR}^{-/-} \mathrm{T}$ cells compared with $\mathrm{WT}$ was associated with increased cytotoxicity and increased aGvHD severity (Figure 2, B and C). Conversely, CD4 $4^{+}$Foxp $-3^{+}$and CD $4^{+} \mathrm{IL}-10^{+}$cells significantly increased in WT versus $\beta 2-\mathrm{AR}^{-1-} \mathrm{T}$ cells after allo-HCT (Figure $2 \mathrm{C}$ ). The percentage of $\mathrm{CD}^{+} \mathrm{T}^{-} \mathrm{bet}^{+}, \mathrm{CD} 8^{+} \mathrm{IFN}-\gamma^{+}$, and $\mathrm{CD} 8^{+} \mathrm{IL}-17^{+}$also increased in $\beta 2-\mathrm{AR}^{-/-}$versus $\mathrm{WT} \mathrm{T}$ cells, while the percentages of $\mathrm{CD}^{+}$Foxp- $3^{+}$and $\mathrm{CD} 8^{+} \mathrm{IL}-10^{+}$in $\beta 2-\mathrm{AR}^{-/-} \mathrm{CD} 8^{+} \mathrm{T}$ cells were unaffected or decreased (Supplemental Figure 1C). There were no significant differences in the naive $\mathrm{T}$ cell phenotype between WT and $\beta 2-\mathrm{AR}^{-/-}$donor $\mathrm{T}$ cells (Supplemental Figure $3 \mathrm{~A}$ ). Naive $\mathrm{T}$ cell populations exhibited comparable T-bet, Foxp-3, and IFN- $\gamma$ frequencies (Supplemental Figure 3A). We excluded the role of $\beta 2-A R$ in the immunosuppressive function of thymic-derived Tregs in donor mice by transplanting BALB/c mice with TCD-BM plus WT or $\beta 2-\mathrm{AR}^{-1-} \mathrm{CD} 4^{+} \mathrm{CD} 25^{-} \mathrm{T}$ cells. $\beta 2-\mathrm{AR}^{-1-} \mathrm{CD} 4^{+} \mathrm{CD} 25^{-} \mathrm{T}$ cells induced more severe aGvHD compared with WT (Supplemental Figure 3B).

We measured the plasma levels of cytokines after allo-HCT to correlate with immune cell populations. Plasma IFN- $\gamma$ on days 7 and 14 and IL-17 levels on day 7 increased significantly, while IL-4 and IL-10 levels decreased significantly in recipients receiving $\beta 2-\mathrm{AR}^{-/-} \mathrm{T}$ cells when compared with WT (Figure $2 \mathrm{D}$ ). There were no differences in plasma GM-CSF, IL-2, IL-6, or TNF- $\alpha$ levels (Figure 2D and Supplemental Figure $3 \mathrm{C}$ ), with IL-12 nondetectable. Thus, donor T cell $\beta 2$-AR expression, especially on $\mathrm{CD}^{+} \mathrm{T}$ cells, after allo-HCT assumes a critical role in shifting the Th1/Th17:Th2/Treg balance toward the Th2/Treg phenotype, limiting cytotoxic T cell development.

The $\beta 2-A R$ agonist bambuterol suppresses the severity of $a G v H D$. $\mathrm{MHC}(\mathrm{B} 6 \rightarrow \mathrm{BALB} / \mathrm{c})$ and $\mathrm{miHA}$ $(\mathrm{B} 6 \rightarrow \mathrm{C} 3 \mathrm{H} / \mathrm{SW})$ mismatched HCT models were used to determine whether $\beta 2-\mathrm{AR}$ agonist treatment affected aGvHD severity and lethality. Lethally irradiated BALB/c and C3H/SW recipients were transplanted using B6 TCD-BM with or without WT T cells. Recipients received daily i.p. injections of saline or bambuterol ( $1 \mathrm{mg} / \mathrm{kg}$ daily). Bambuterol is a prodrug of the $\beta 2$-AR selective agonist terbutaline, which is formed after enzymatic conversion by butyrylcholinesterase, an enzyme present in multiple tissues, including the intestine, serum, lungs, liver, and heart. Bambuterol was used because it is longer acting and has a superior side-effect profile compared with terbutaline. Injections continued for 30 days after allo-HCT, starting on day 0. Compared with saline-treated mice, bambuterol treatment significantly ameliorated aGvHD in the MHC (Figure 3A) and miHA (Figure 3B) mismatched models, as assessed by weight loss, clinical score, and survival. Donor $\mathrm{T}$ cells were isolated from spleen and liver at days 7 and 14 after allo-HCT, and flow cytometric analysis of transcription factor and cytokine expression in $\mathrm{CD}^{+}$and $\mathrm{CD}^{+} \mathrm{T}$ cells in bambuterol-treated mice showed significantly increased $\mathrm{CD} 4^{+}$Foxp- $3^{+}$ and $\mathrm{CD} 4^{+} \mathrm{IL}-10^{+}$and decreased $\mathrm{CD} 4^{+} \mathrm{T}_{-}$bet $^{+}, \mathrm{CD} 4^{+} \mathrm{IFN}-\gamma^{+}$, and $\mathrm{CD} 4^{+} \mathrm{IL}-17^{+}$populations (Figure $3 \mathrm{C}$ ). Bambuterol also significantly increased $\mathrm{CD} 8^{+}$Foxp $-3^{+}$and $\mathrm{CD} 8^{+} \mathrm{IL}-10^{+}$, while decreasing $\mathrm{CD} 8^{+} \mathrm{T}^{-}$bet $^{+}$, $\mathrm{CD} 8^{+} \mathrm{IFN}-\gamma^{+}$, and $\mathrm{CD} 8^{+} \mathrm{IL}-17^{+}$populations (Supplemental Figure 4). To investigate whether bambuterol treatment had an adverse effect on cardiovascular function, heart rate (HR) and blood pressure (BP) were measured at expected peak bambuterol levels. There was no difference in BP and HR between treatment and control recipients (Supplemental Figure 5).

$\beta 2-A R$ activation stimulates Treg generation. Previous studies have shown that $\beta 2-\mathrm{AR}$ signaling increases the immunosuppressive function of Tregs $(34,35)$. Therefore, we focused on the role of $\beta 2$-AR in vitro in induced Treg (iTreg) generation and Th1 suppression. iTregs and Th1 cells were generated from naive $\mathrm{T}$ cells in vitro by culture in Treg media plus IL-2, TGF- $\beta$, and anti-CD28/CD3 stimulation for Tregs and with the IL- 2 and IL-12 for Th1 cells. Sorted B6 CD4 ${ }^{+} \mathrm{T}$ cells were cultured in Treg media in the presence or absence of terbutaline (the active bambuterol metabolite considering bambuterol requires in vivo metabolism to terbutaline). Terbutaline significantly increased iTregs, and this was reversible by treatment with the pan- $\beta$-AR antagonist propranolol (Figure $4 \mathrm{~A}$ ). Considering that previous reports have demonstrated 
A

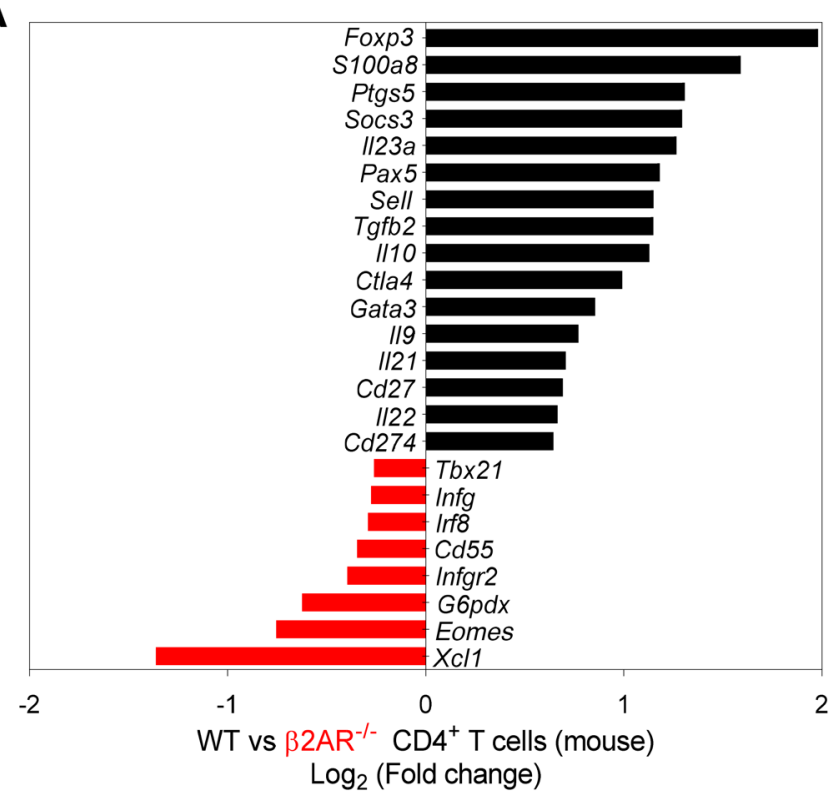

B

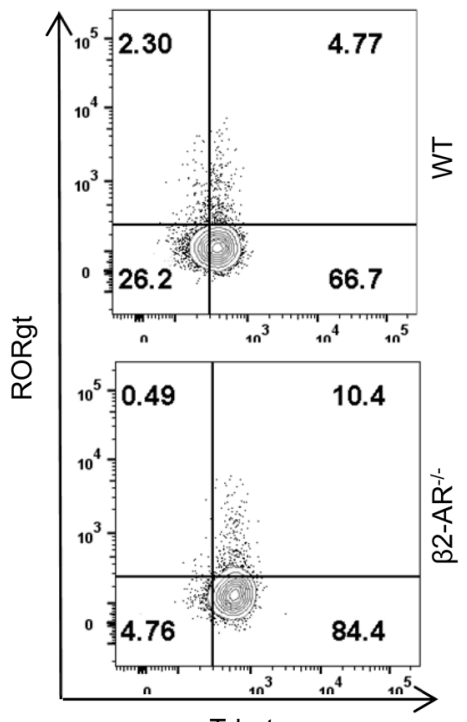

T-bet

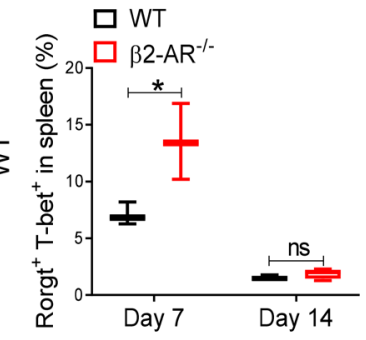

$\square$ WT

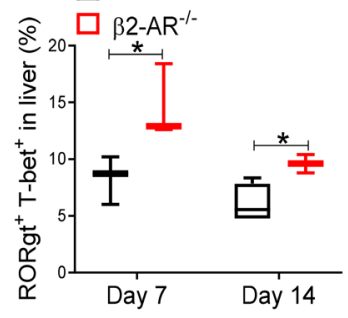

C $\square \mathrm{WT}$

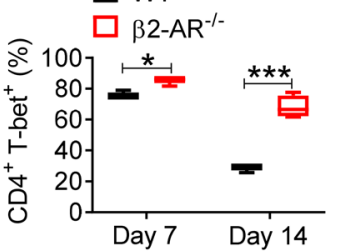

$\square$ WT
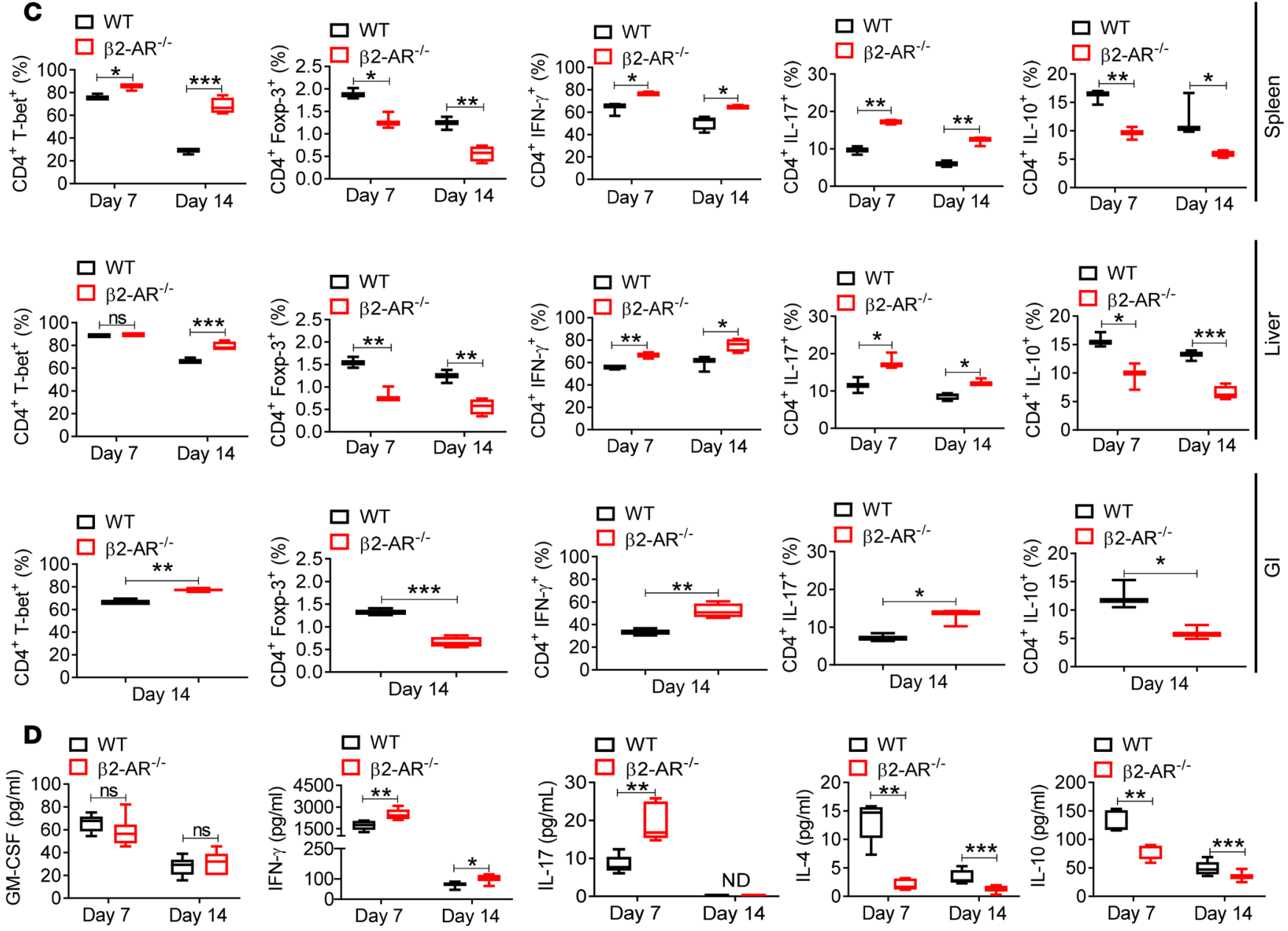

Figure 2. Expression of $\boldsymbol{\beta 2}$-ARs on $\mathrm{T}$ cells regulates the $\mathrm{T}$ cell phenotype during allogeneic responses. (A) Immune-related gene expression in WT or $\beta 2-\mathrm{AR}^{-1-} \mathrm{CD}^{+} \mathrm{T}$ cells sorted from spleen at day 14 after allo-HCT in the B6 $\rightarrow \mathrm{BALB} / \mathrm{c}$ model transplanted with $3.5 \times 10^{6} \mathrm{WT}$ C57BL/6 TCD-BM alone or combined with $0.7 \times 10^{6}$ WT C57BL/6 or $\beta 2-\mathrm{AR}^{-/-}$pan-T cells using NanoString nCounter Immunology Panel mRNA microarray (splenocytes pooled from 5-6 mice before CD4+ $\mathrm{T}$ cell sorting). (B) ROR $\gamma \mathrm{t}^{+} \mathrm{T}$-bet ${ }^{+}$frequencies in liver and spleen $\mathrm{CD} 4^{+} \mathrm{T}$ cells within single live $\mathrm{H}-2^{\mathrm{b}+} \mathrm{H}-2^{\mathrm{d}-}-\mathrm{CD} 45^{+} \mathrm{CD} 3^{+}$cells 7 and 14 days after allo-HCT. There are increased ROR $\gamma \mathrm{t}^{+} \mathrm{T}$-bet ${ }^{+} \mathrm{CD} 4^{+} \mathrm{T}$ cells in recipients of $\beta 2-\mathrm{AR}^{-1-} \mathrm{T}$ cells. Representative plots are shown from 2 independent experiments

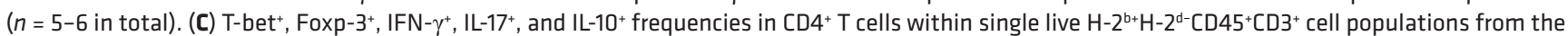


spleen and liver at days 7 and 14, and the GI tract 14 days after allo-HCT. Data pooled from 2 individual experiments, total $n=5-6$ per group. B6 $\rightarrow$ BALB/c model using B6 $\rightarrow$ BALB/c model transplanted with $3.5 \times 10^{6}$ WT C57BL/6 TCD-BM alone or combined with $0.7 \times 10^{6} \mathrm{WT}^{\mathrm{C}} \mathrm{C} 7 \mathrm{BL} / 6$ or $\beta 2-\mathrm{AR}{ }^{-/-}$pan-T cells.

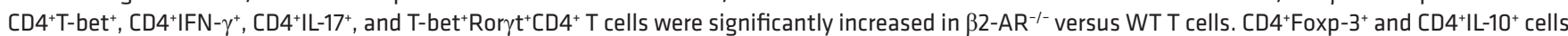
significantly increased in WT versus $\beta 2-A R^{-1-}$ T cells. (D) Plasma levels of inflammatory/inhibitory cytokines of irradiated BALB/c mice transplanted with TCD-BM plus WT or $\beta 2-\mathrm{AR}^{-/-}$T cells at 7 and 14 days. Plasma IFN- $\gamma$ on days 7 and 14 and IL-17 levels on day 7 increased significantly, while IL-4 and IL-10 levels decreased significantly in $\beta 2-\mathrm{AR}^{-1-} \mathrm{T}$ cell recipients. There were no differences in plasma GM-CSF levels. For comparison of the means, an unpaired 2-tailed $t$ test was used in $\mathbf{B}, \mathbf{C}$, and $\mathbf{D}$. ${ }^{*} P<0.05$, ${ }^{* *} P<0.01$, ${ }^{*}{ }^{*} P<0.001$. Data are presented as median \pm min to max.

that glycogen synthase kinase-3 (GSK-3) activity plays a role in regulating the immunosuppressive function of Tregs $(36,37)$ - and that $\beta$-AR stimulation has been shown to be dependent on GSK-3 activity in other cell types, like cardiomyocytes $(38,39)$ - we investigated whether $\beta 2$-AR signaling increased iTreg generation by modulating GSK-3 activity. The GSK-3 mechanism of action is unique in that it is a constitutively active kinase that is inhibited by phosphorylation at either the serine- 9 or serine- 21 residues of GSK-3 $\beta$ and GSK-3 $\alpha$, respectively (40). Therefore, to investigate the functional state of GSK-3, we assessed the phosphorylation status of these key amino acids by Western blot. Surprisingly, treatment with terbutaline during iTreg generation promoted a more rapid dephosphorylation of GSK-3 than was observed when terbutaline's function was blocked by propranolol treatment (Figure 4B), suggesting that $\beta 2$-AR signaling promotes iTreg development by increasing GSK-3 activity. One to 3 days after starting iTreg development, we did not detect phosphorylated GSK-3 (Figure 4B). To confirm the positive role of GSK-3 activation in iTreg differentiation, $\mathrm{CD}^{+} \mathrm{T}$ cells were cultured in the presence or absence of SB216763, a selective GSK-3 inhibitor resulting in significantly decreased Treg generation. Furthermore, terbutaline did not increase iTreg differentiation in the presence of SB216763 to the same degree as observed in the absence of SB216763 (Figure 4C). To investigate the effects of the $\beta 2-\mathrm{AR}$ agonist on Th1 differentiation, naive CD4 ${ }^{+}$ $\mathrm{T}$ cells were cultured in Th1 culture media supplemented by IL-12 and IL-2 cytokines, with or without terbutaline. Terbutaline significantly decreased the expression of T-bet and IFN- $\gamma$ in CD4 ${ }^{+} \mathrm{T}$ cells, and this effect was reversed by propranolol (Supplemental Figure 6, A and B). These data further demonstrate that GSK-3 signaling through $\beta 2$-AR agonism positively affects iTreg generation.

Selective $\beta 2-A R$ agonism increases the generation of donor-derived myeloid cells. MDSCs have been shown to affect aGvHD severity (41). We recently showed that $\beta 2-\mathrm{AR}$ signaling positively enhances the function and generation of endogenous MDSCs in models of solid tumor killing (26). We investigated the effect of $\beta 2-\mathrm{AR}$ agonism on BM-derived donor MDSCs during allo-HCT. Lethally irradiated BALB/c mice were transplanted with B6 TCD-BM and WT T cells and received i.p. injections of bambuterol or saline starting on day 0 after allo-HCT. Bambuterol significantly increased MDSCs (CD $11 \mathrm{~b}^{+} \mathrm{Gr}-1^{+}$population) in spleen and liver compared with controls (Figure 5A). To examine the effect of $\beta 2$-AR signaling on MDSC generation, BM from WT or $\beta 2-\mathrm{AR}^{-/-}$mice were grown in MDSC media (IL-6 and GM-CSF), with or without terbutaline. Terbutaline significantly increased in vitro MDSC generation from WT but not $\beta 2-\mathrm{AR}^{-/-} \mathrm{BM}$ (Figure 5, B and C). To exclude any nonspecific activity of terbutaline on MDSC generation, propranolol abrogated the effect of terbutaline (Figure $5 \mathrm{~B}$ ). To confirm the specific role of the $\beta 2-\mathrm{AR}$ on BM cells and MDSC generation, lethally irradiated BALB/c mice were transplanted with WT (CD45.1) and $\beta 2-\mathrm{AR}^{-/}$ (CD45.2) TCD-BM mixed at a 50:50 ratio plus T cells (CD45.2). Recipients were treated with daily i.p. bambuterol or saline (Figure $5 \mathrm{D}$ ). WT and $\beta 2-\mathrm{AR}^{-/}$MDSCs were analyzed from spleen and liver on day 7 , and WT MDSC percentages were found to be significantly higher in the spleen and liver compared with $\beta 2-\mathrm{AR}^{-/-} \mathrm{MDSC}$ percentages (Figure 5D).

Selective $\beta 2-A R$ agonism suppresses aGvHD severity in a humanized mouse model. $\beta 2-\mathrm{AR}$ signaling during murine allo-HCT increased donor MDSCs, decreased donor Th1 cells, elevated donor Tregs, and decreased aGvHD severity and lethality. We investigated whether $\beta 2$-AR signaling by bambuterol ameliorates the severity and fatality of aGvHD in a humanized model. Xenogeneic NOD-scid IL-2R $\gamma^{-1-}$ (NSG-HLA-A2) mice were sublethally irradiated $(2.5 \mathrm{~Gy})$, transplanted with human peripheral blood mononuclear cells (PBMCs, $2 \times 10^{6}$ cells), and treated with daily i.p. injections of bambuterol $(1 \mathrm{mg} / \mathrm{kg}$ ) or saline (starting on day 0 for 30 days after allo-HCT). Bambuterol significantly decreased aGvHD severity compared with controls (Figure 6A). After bambuterol treatment, when compared with saline, the percentage of human donor immunosuppressive cells $\mathrm{CD} 4^{+} \mathrm{Foxp}-3^{+}, \mathrm{CD} 4^{+} \mathrm{IL}-10^{+}$, and $\mathrm{CD} 14^{+} \mathrm{CD} 33^{+}$(MDSCs) increased and the cytotoxic cells $\mathrm{CD} 4^{+} \mathrm{IFN}-\gamma^{+}(\mathrm{Th} 1)$ and $\mathrm{CD} 4^{+} \mathrm{IL}-17^{+}$(Th17) decreased, respectively, in spleen, liver, and lung at day 14. (Figure 6B). We found the same pattern in human donor $\mathrm{CD} 8^{+} \mathrm{T}$ cells (Supplemental Figure 7), 
A

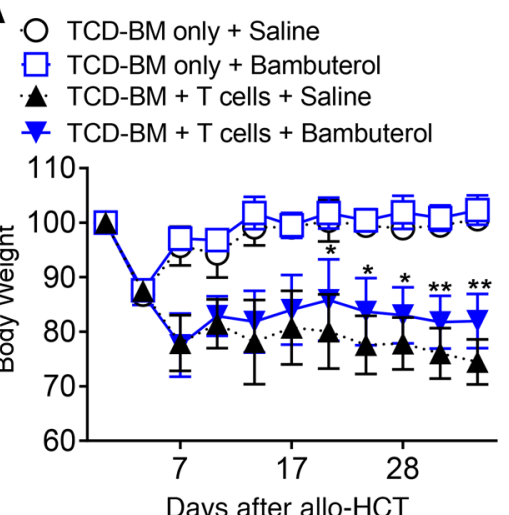

B

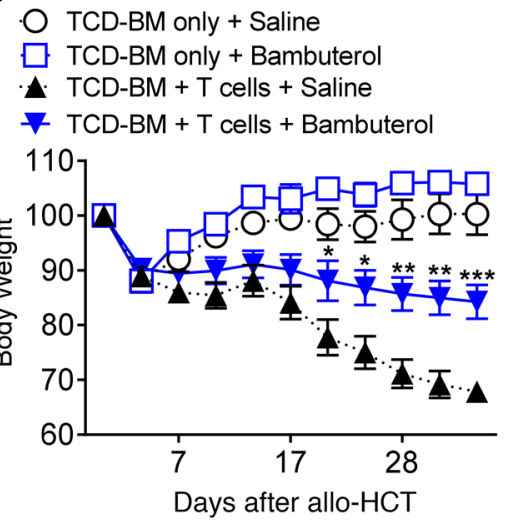

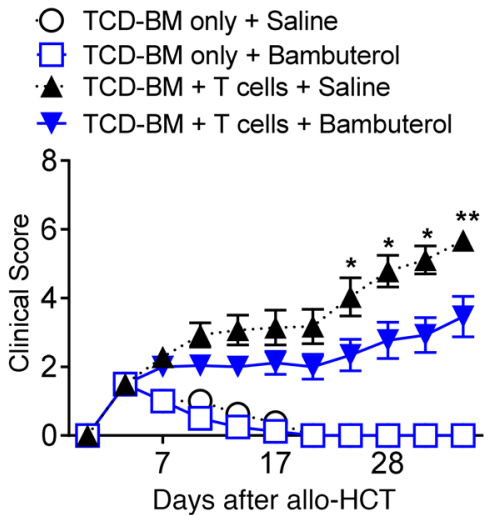
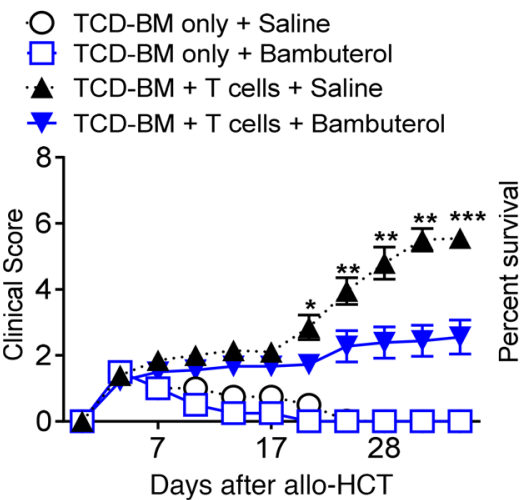
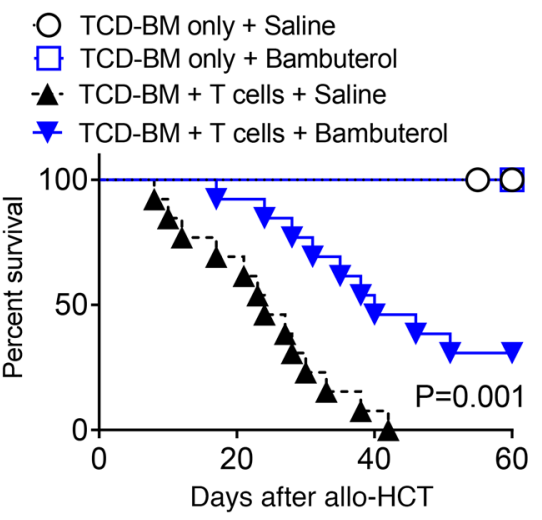

- TCD-BM only + Saline

$\square$ TCD-BM only + Bambuterol

-A. TCD-BM + T cells + Saline

F $\mathrm{TCD}-\mathrm{BM}+\mathrm{T}$ cells + Bambuterol

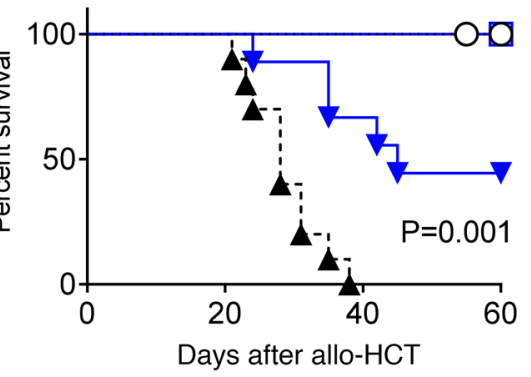

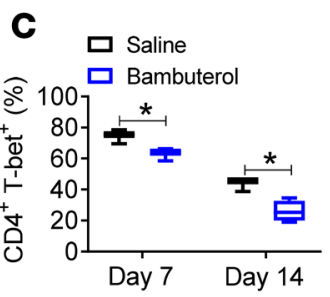
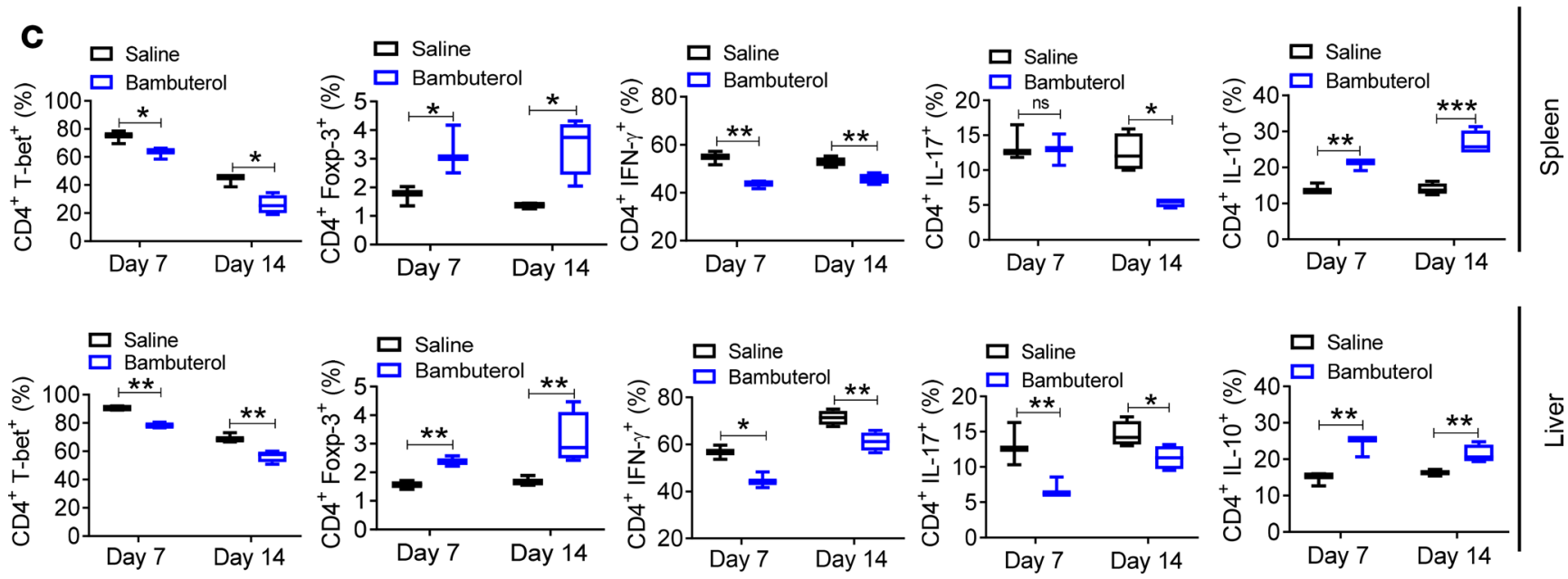

Figure 3. The selective $\mathbf{\beta 2 - A R}$ agonist bambuterol ameliorates the severity and fatality of acute GvHD. (A) Body weight, clinical score, and survival of lethally irradiated BALB/c mice after allo-HCT with $3.5 \times 10^{6}$ WT C57BL/6 TCD-BM alone or combined with $0.7 \times 10^{6} \mathrm{WT}$ C57BL/6 pan-T cells treated with daily injections of saline and bambuterol. Data pooled from 2 individual experiments; $n=6-8$ per group for a total of $n=12-16$ per group. (B) Body weight, clinical score, and survival of lethally irradiated C3H/SW mice after allo-HCT with $3.5 \times 10^{6}$ WT C57BL/6 TCD-BM alone or combined with $1.5 \times 10^{6}$ WT C57BL/ 6 pan-T cells treated with daily injections of saline and bambuterol. Data pooled from 2 individual experiments; $n=4-7$ per group for a total of $n=8-14$ per group. Bambuterol significantly ameliorated aGvHD in the MHC and miHA mismatched models, as assessed by weight loss, clinical score, and survival. (C) T-bet ${ }^{+}$, Foxp $-3^{+}$, IFN- $\gamma^{+}$, IL- $-17^{+}$, and IL- $10^{+}$frequencies in CD4 ${ }^{+}$T cells within single live $\mathrm{H}-2^{\mathrm{b}+} \mathrm{H}-2^{\mathrm{d}-}-\mathrm{CD} 45^{+} \mathrm{CD} 3^{+}$cell populations from spleen and liver of mice 7 and 14 days after allo-HCT in the B6 $\rightarrow$ BALB/c model transplanted with $3.5 \times 10^{6}$ WT C57BL/6 TCD-BM combined with $0.7 \times 10^{6}$ WT C57BL/ 6 pan-T cells treated with daily injections of saline and bambuterol at ST. Data pooled from 2 individual experiments; total $n=5-6$ per group. There were significantly increased $C D 4^{+}$Foxp $-3^{+}$and $C D 4^{+} I L-10^{+}$and decreased $C D 4^{+} T-$ bet $^{+}, C D^{+} I F N-\gamma^{+}$, and $C D 4^{+} I L-17^{+}$populations in the bambuterol-treated recipients. For comparison of survival curves, a log-rank (Mantel-Cox) test was used in $\mathbf{A}$ and $\mathbf{B}$. For comparison of the means, an unpaired 2-tailed $t$ test was used in C. Two-way ANOVA with Tukey's multiple comparisons test was used for body weight and clinical score difference in $\mathbf{A}$ and $\mathbf{B} .{ }^{*} P<0.05,{ }^{* *} P<0.01,{ }^{* *} P<0.001$. Body weight, clinical score, and survival data are shown as means $\pm \mathrm{SEM}$. Other data are presented as median \pm min to max. 
A No Treg media
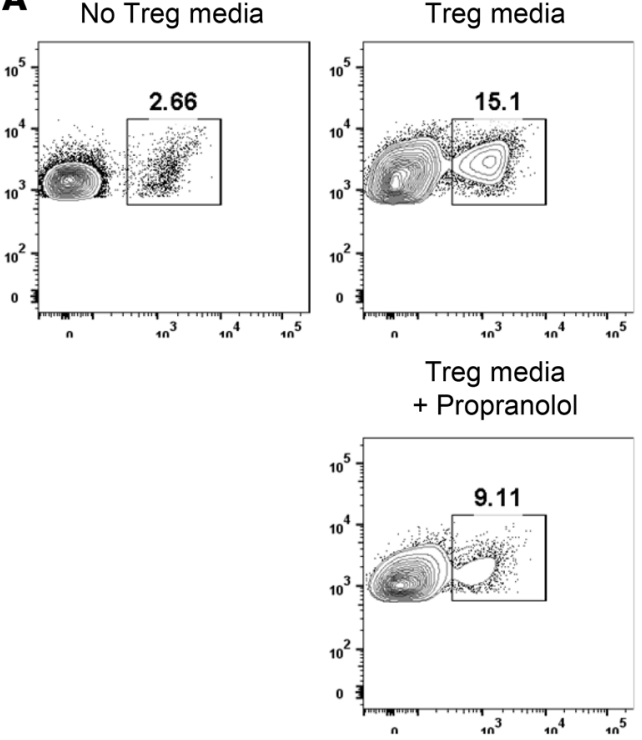

Treg media + Terbutaline

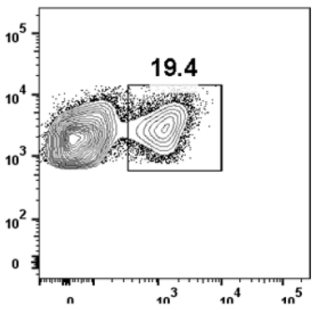

Treg media + Terbutaline + Propranolol

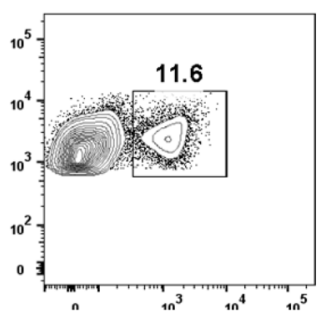

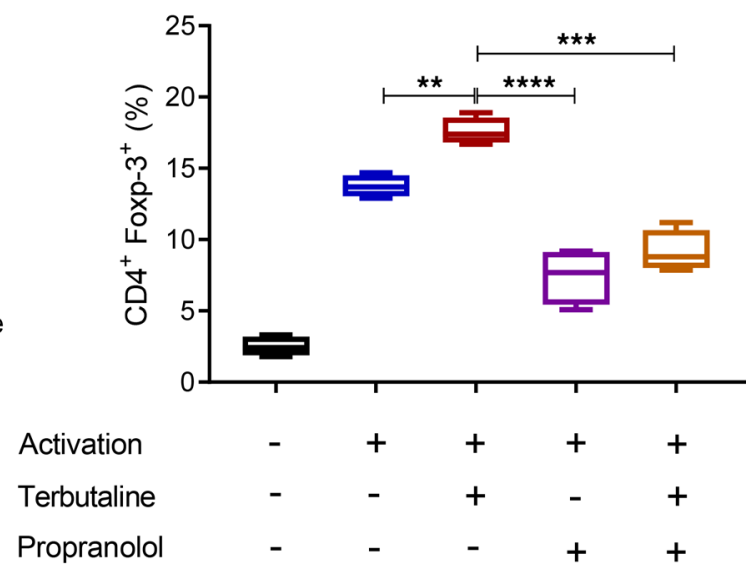

B
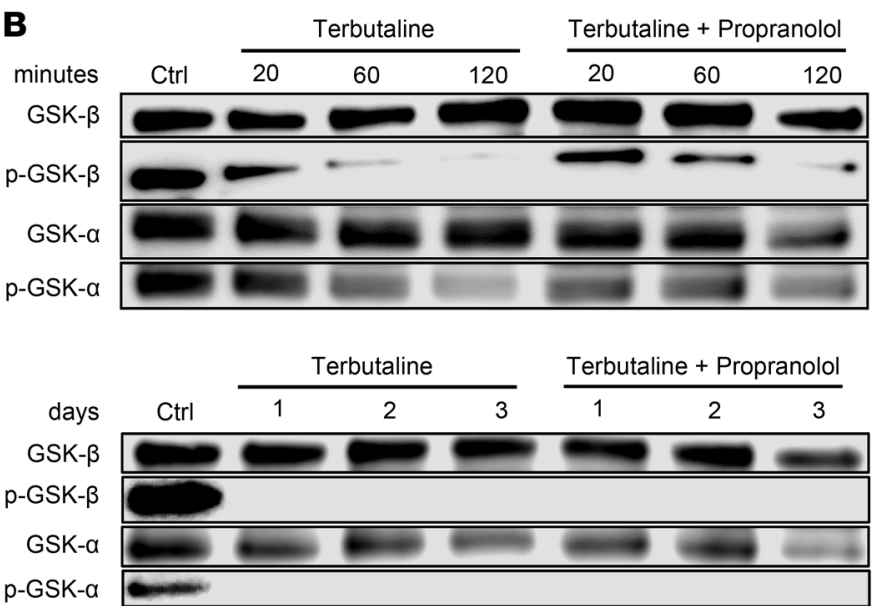

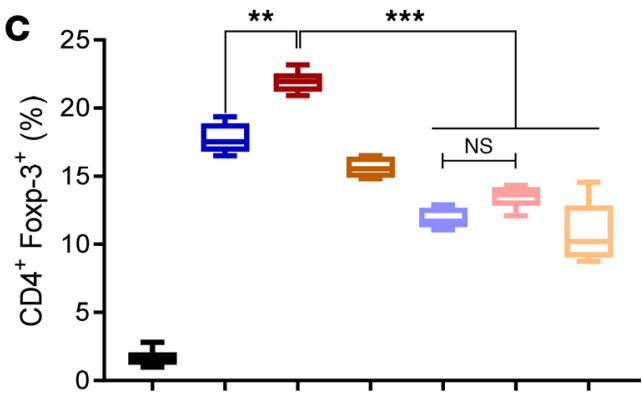

$\begin{array}{lccccccc}\text { Activation } & - & + & + & + & + & + & + \\ \text { Terbutaline } & - & - & + & + & - & + & + \\ \text { Propranolol } & - & - & - & + & - & - & + \\ \text { SB 216763 } & - & - & - & - & + & + & +\end{array}$

Figure 4. 32 -ARs on $T$ cells play a critical role in development of Treg through GSK-3 signaling. (A) CD4+ $T$ cells sorted from healthy $C 57 B L / 6$ mouse spleens were cultured in Treg media (TCF- $\beta+$ IL-2) plus CD3/C28 with terbutaline with and without the pan- $\beta$-AR antagonist propranolol. Foxp- $3^{+}$ $T$ cell frequencies within single live $\mathrm{CD}^{+} \mathrm{T}$ cell populations were analyzed using flow cytometry. Terbutaline significantly increased iTregs, and this was reversible by propranolol. Data pooled from 3 individual experiments; $n=2-3$ replicates per group. (B) CD4 ${ }^{+}$T cells sorted from healthy C57BL/6 mouse spleens were activated in Treg media plus CD3/C28 in the presence of terbutaline or terbutaline plus propranolol. The phosphorylation of GSK-3 $\alpha$ and GSK-3 $\beta$ were analyzed by Western blot in T cells before terbutaline activation (control) and at 20, 60, and 120 minutes or 1,2 , and 3 days after $\mathrm{CD}^{+} \mathrm{T}$ cell activation. A representative blot of 3 independent experiments is presented. Terbutaline promoted GSK-3 dephosphorylation in CD4 T cells in Treg media, an effect decreased by propranolol. No phosphorylated GSK-3 was detected 1-3 days after starting iTreg development. (C) CD4+ T cells sorted from healthy C57BL/6 mouse spleens were activated in Treg media plus CD3/C28. Culture conditions included terbutaline, terbutaline plus propranolol, the GSK-3 inhibitor SB216763 alone, terbutaline plus SB216763, and terbutaline, propranolol, and SB216763 together. At day 3, Tregs were quantified using Foxp-3 gating on live $C D 3^{+} C D 4^{+}$cell populations. SB216763 resulted in significantly decreased Treg generation. SB216763 resulted in a decrease in the terbutaline induced iTreg differentiation. One-way ANOVA with Bonferroni's post hoc test was used in $\mathbf{A}$ and $\mathbf{C}$. ${ }^{* *} P<0.01$, ${ }^{* *} P<0.001,{ }^{* * *} P<0.0001$. Data are presented as median \pm min to max.

suggesting that selective $\beta 2$-AR activation ameliorates $\mathrm{aGvHD}$ by suppressing human donor inflammatory $\mathrm{T}$ cells and by increasing donor suppressive cells in a human immune cell NSG model.

Selective $\beta 2-A R$ agonism preserves GvT activity. The immune responses leading to aGvHD tissue damage and tumor elimination due to the GvT effect cannot be readily separated (42). To investigate whether bambuterol treatment affected the GvT effect in the MHC-mismatched HCT model, GFP luciferase ${ }^{+}$A20 B cell lymphoma cells (A20-GFP-Luc, $1.0 \times 10^{5}$ cells) were injected into lethally irradiated BALB/c recipients 4 hours before HCT with WT B6 TCD-BM and B6 WT splenic T cells. Tumor growth was monitored by bioluminescent imaging (BLI). Recipients of A20 cells and TCD-BM alone died before day 28 (Figure 7, A-C). Tumor growth was controlled in recipients receiving WT T cells and bambuterol, resulting in significant 
A
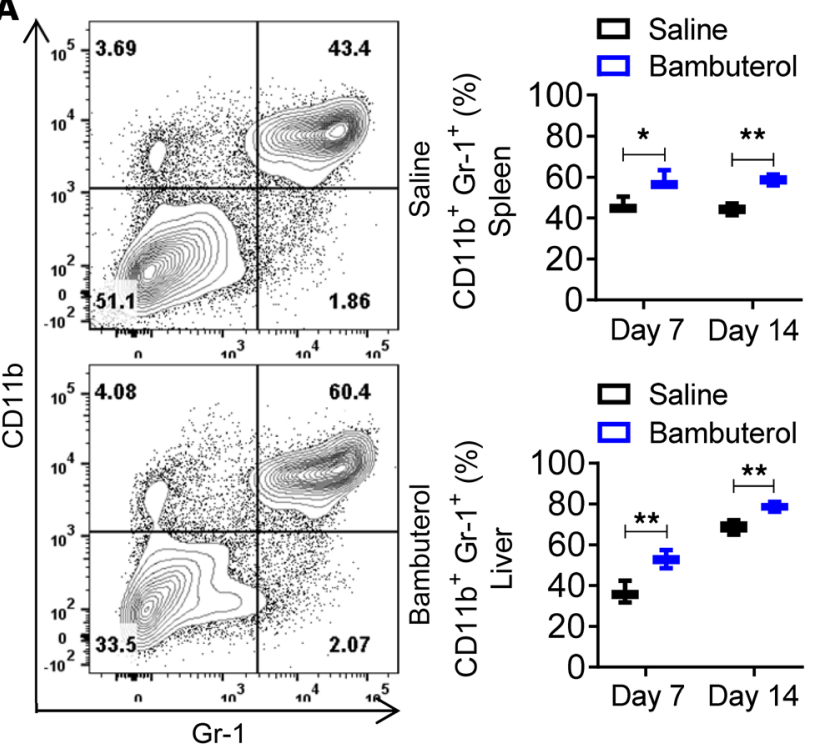

B

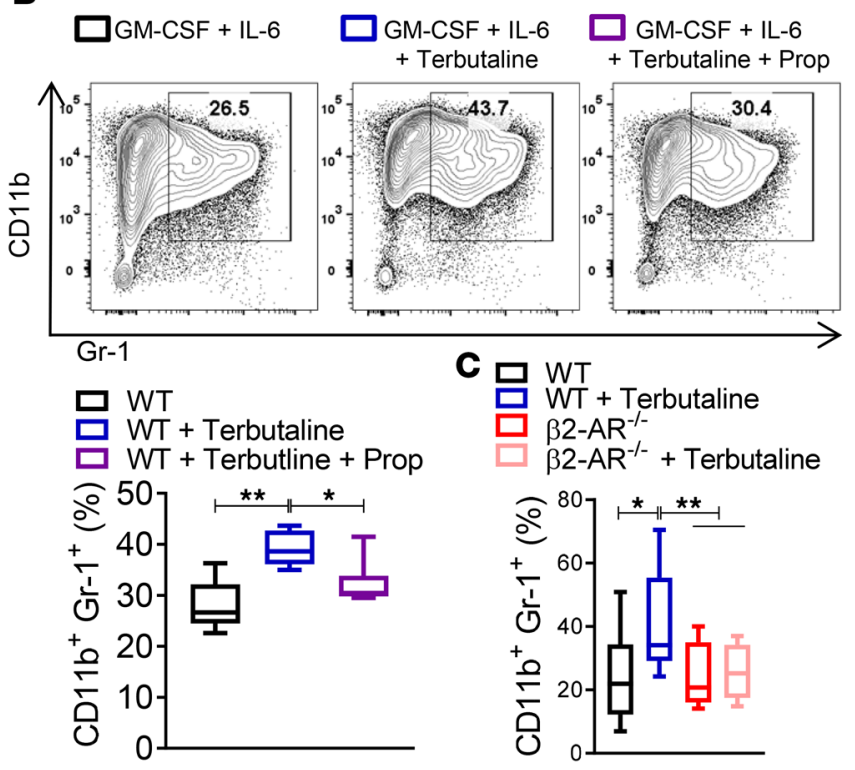

D

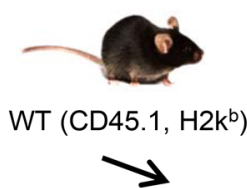
Mix CD45.1 TCD-BM
and CD45.2 TCD-BM at 50:50 ratio

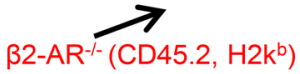

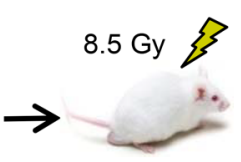

WT BALB/C (CD45.2, $\mathrm{H}_{2} \mathrm{k}^{\mathrm{d}}$ )

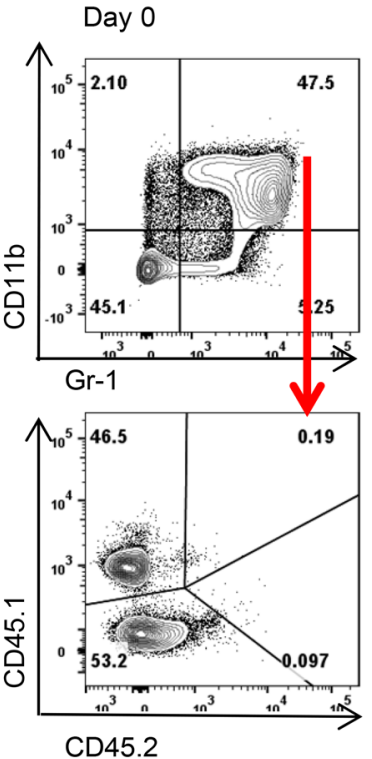

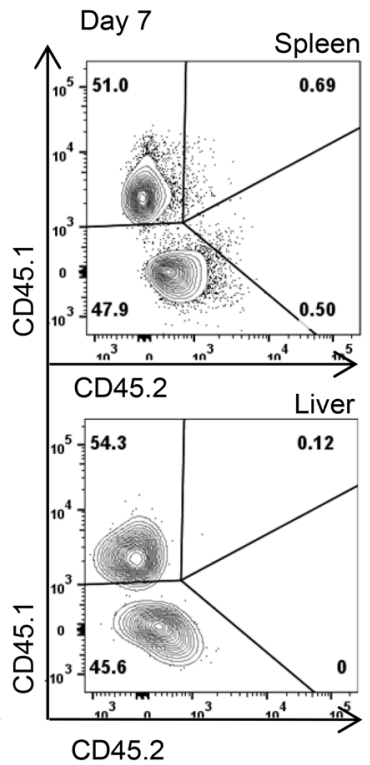

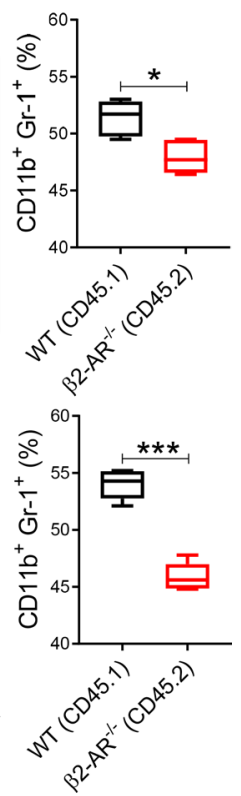

Figure 5. The selective $\beta 2$-AR agonist bambuterol increases the generation of donor BM-derived myeloid-derived suppressor cells (MDSCs). (A) CD11b $\mathrm{b}^{-} \mathbf{1}^{+}$ (MDSC) frequencies within single live $\mathrm{H}-2^{\mathrm{b}+} \mathrm{H}-2^{\mathrm{d}-} \mathrm{CD} 45^{+}$populations from spleens and liver, 7 and 14 days after allo- $\mathrm{HCT}$ in the B6 $\rightarrow \mathrm{BALB} / \mathrm{C}$ model transplanted with $3.5 \times 10^{6}$ WT C57BL/6 TCD-BM combined with $0.7 \times 10^{6}$ WT C57BL/6 pan-T cells treated with daily saline and bambuterol injections. Data pooled from 2 individual experiments; total $n=5-6$ per group. Bambuterol significantly increased MDSCs in spleen and liver compared with controls. (B) In vitro generation of BM MDSCs isolated from WT C57BL/6 mice in presence of terbutaline or terbutaline plus propranolol. Data pooled from 3 individual experiments, each with 2-3 replicates per group. Terbutaline significantly increased in vitro MDSC generation, which was blocked by propranolol. (C) In vitro generation of BM MDSCs isolated from WT or $\beta 2-\mathrm{AR}^{-1-} \mathrm{C} 5 \mathrm{BBL} / 6$ mice in presence of terbutaline. Data pooled from 3 individual experiments, each with 2-3 replicates per group. Terbutaline significantly increased in vitro MDSC generation from WT but not $\beta 2-A R^{-/-} B M$. (D) Schematic design and MDSC generation from WT (CD45.1 H-2 $2^{b}$ ) and $\beta 2-\mathrm{AR}^{-1-}\left(\mathrm{CD} 45.2 \mathrm{H}-2^{\mathrm{b}}\right) \mathrm{TCD}-\mathrm{BM}$ gated on single live $\mathrm{H}-2^{\mathrm{d}-} \mathrm{CD}^{-}$cells. Lethally irradiated BALB/c mice were transplanted with $3.5 \times 10^{6} \mathrm{WT}(\mathrm{CD} 45.1)$ and $\beta 2-\mathrm{AR}^{-1}$ (CD45.2) C57BL/6 TCD-BM (50:50 ratios) combined with $0.7 \times 10^{6}$ WT (CD45.2) C57BL/6 pan-T cells. Recipients were treated with daily bambuterol injections. Data pooled from 2 individual experiments, each with $n=5$ per group obtaining a total of $n=10$ per group. At day 7 after allo-HCT, liver and spleen WT MDSC percentages were significantly higher compared with $\beta 2-\mathrm{AR}^{-1-}$. For comparison of the means, an unpaired 2-tailed $t$ test was used in $\mathbf{A}$ and $\mathbf{D}$, and a 1 -way ANOVA with Bonferroni's post hoc test was used in $\mathbf{B}$ and $\mathbf{C}$. ${ }^{*} P<0.05,{ }^{* *} P<0.01,{ }^{* * *} P<0.001$. Data are presented as median \pm min to max.

survival improvement (Figure 7B). When the donor T cells were decreased (from $5 \times 10^{5}$ to $2 \times 10^{5}$ ), recipient mice did not develop severe aGvHD, and bambuterol treatment did not diminish the GvT effect (Figure 7C). NKG2D expression by T cells has been associated with an increased GvT effect, with minimal effect on GvHD severity $(43,44)$. Furthermore, MDSCs enhance the GvT effect by increasing expression of NKG2D 
A

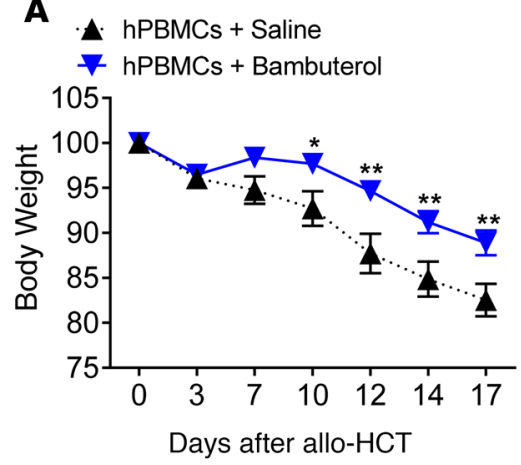

B
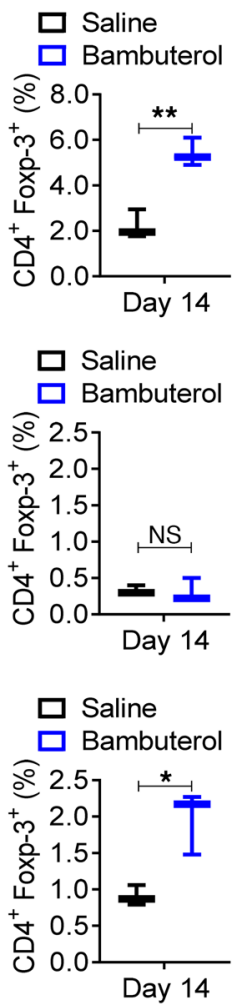
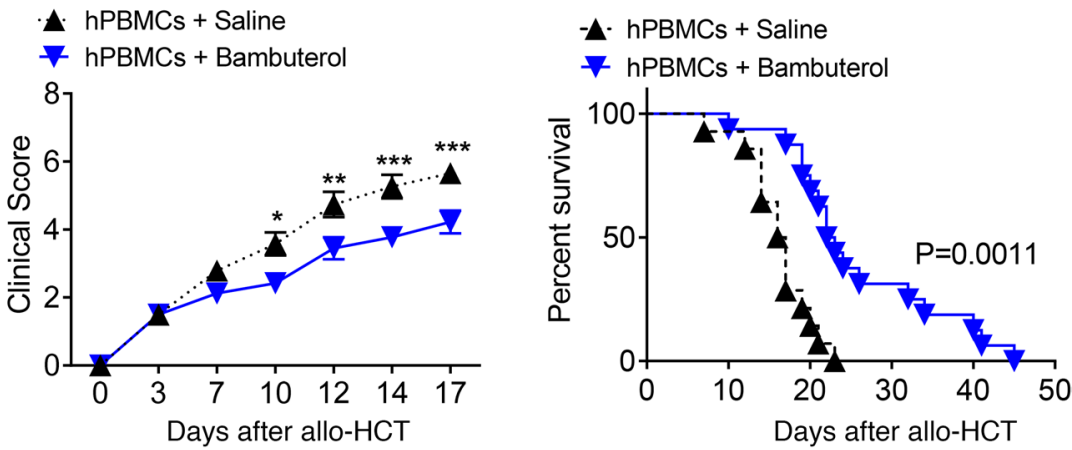
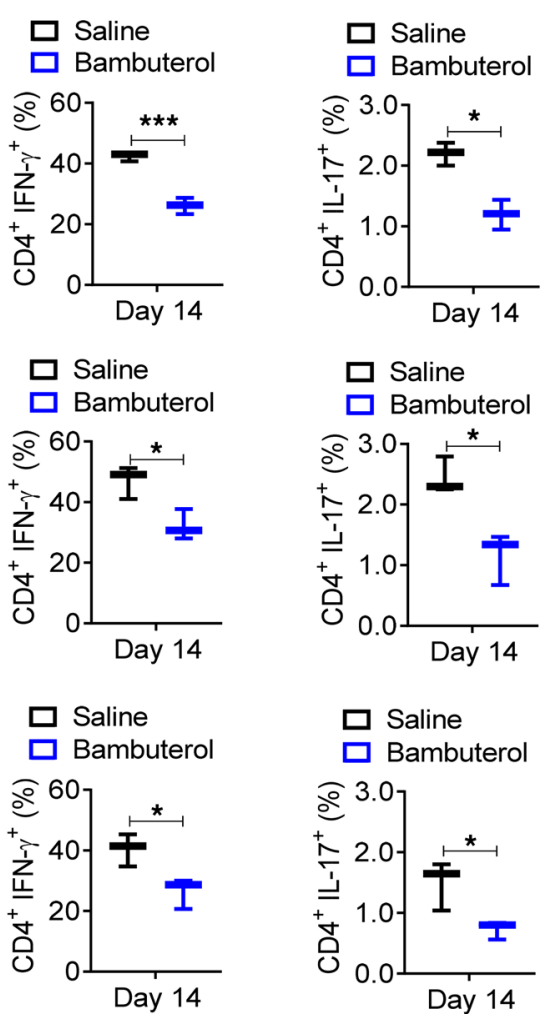

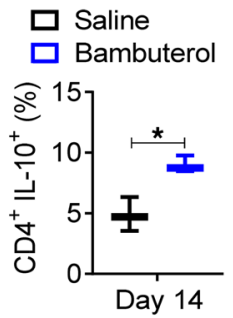

$\square$ Saline
$\square$ Bambuterol
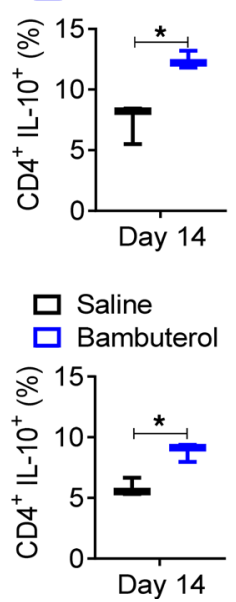
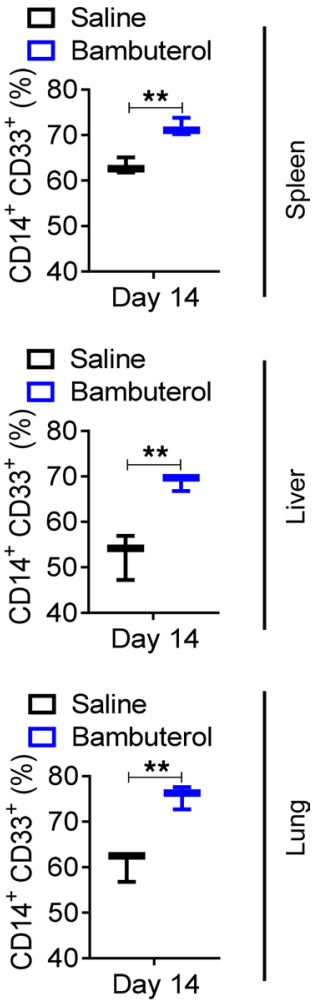

Figure 6. The selective $\beta 2$-AR agonist bambuterol ameliorates the severity and fatality of acute GvHD in a humanized NSG model. (A) Body weight, clinical score, and survival of lethally irradiated NSG mice after allo-HCT with $2 \times 10^{6}$ human PBMCs. Mice were treated with daily injections of saline and bambuterol. Data pooled from 2 individual experiments, each with $n=8-10$ per group to obtain total of $n=16-20$ per group. Bambuterol signifi-

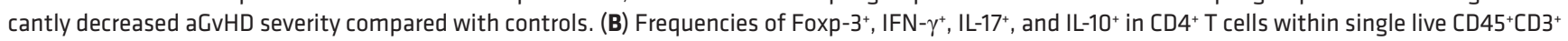
populations from spleen, liver, and lungs of mice 14 days after allo-HCT. MDSCs were gated from single live CD45+CD3- populations. Data pooled from 2 individual experiments, each with $n=2-3$ per group to obtain total of $n=4-6$ per group. Bambuterol treatment increased the percentage of human donor immunosuppressive cells CD4+Foxp- $3^{+}$, CD4+IL-10+, and CD14+CD33+ (MDSCs) cells and decreased the cytotoxic cells CD4+IFN- $\gamma^{+}$(Th1) and CD4 $4^{+}$IL-17 $7^{+}$(Th17) cells. For comparison of survival curves, a log-rank (Mantel-Cox) test was used in A. For comparison of the means, an unpaired 2-tailed $t$ test was used in B. Two-way ANOVA with Tukey's multiple comparisons test was used for body weight and clinical score difference in $\mathbf{A}$. ${ }^{*} P<0.05$, ${ }^{* *} P<0.01,{ }^{* * *} P<0.001$. Body weight, clinical score, and survival data are shown as means $\pm \mathrm{SEM}$. Other data are presented as median \pm min to max.

in effector cells (44). We tested whether bambuterol promotes the induction of antitumor effector cells, leading to tumor control. Compared with saline, bambuterol treatment significantly increased the expression of NKG2D in effector cell populations (Figure 7D), and NKG2D expression in $\beta 2-\mathrm{AR}^{-/-} \mathrm{CD} 4^{+}$effector T cells was also significantly lower than $\mathrm{WT} \mathrm{CD}^{+}$effector T cells (Supplemental Figure 8).

\section{Discussion}

We report that $\beta 2$-ARs expressed by $\mathrm{T}$ cells during allo-HCT modulate $\mathrm{T}$ cell differentiation and effector cell function. Th1 and Th17 CD4 ${ }^{+} \mathrm{T}$ cell polarization in vitro induces aGvHD in target organs including 
A

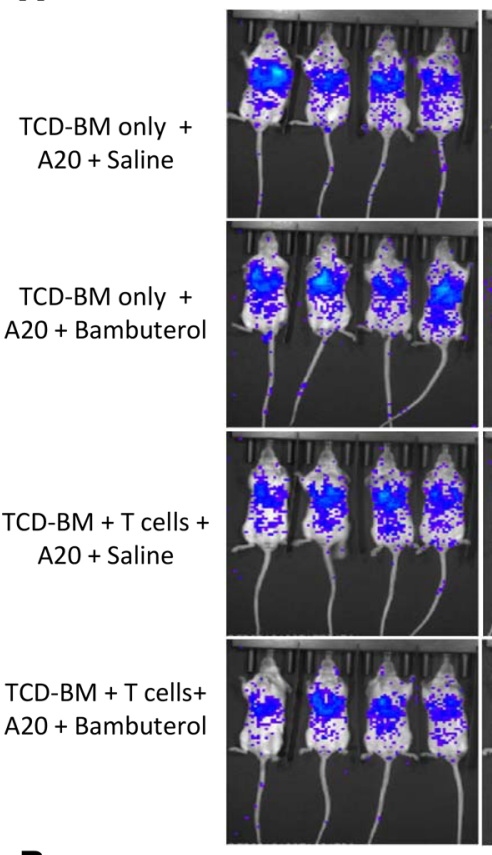

B

O TCD-BM only + Saline

․ TCD-BM only + Bambuterol

- $\mathrm{TCD}-\mathrm{BM}+\mathrm{T}$ cells + Saline

. TCD-BM + T cells + Bambuterol

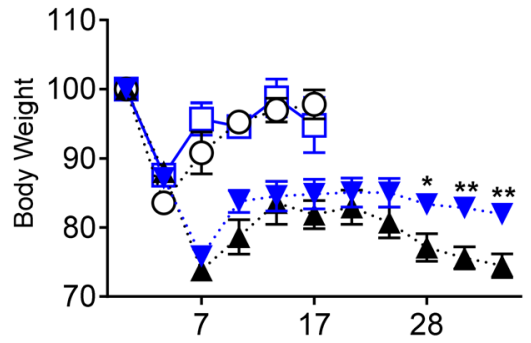

Days after allo-HCT

-O. TCD-BM only + Saline

C $\square$ TCD-BM only + Bambuterol

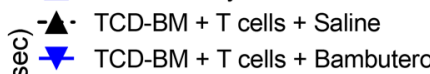

离 $10^{8}$
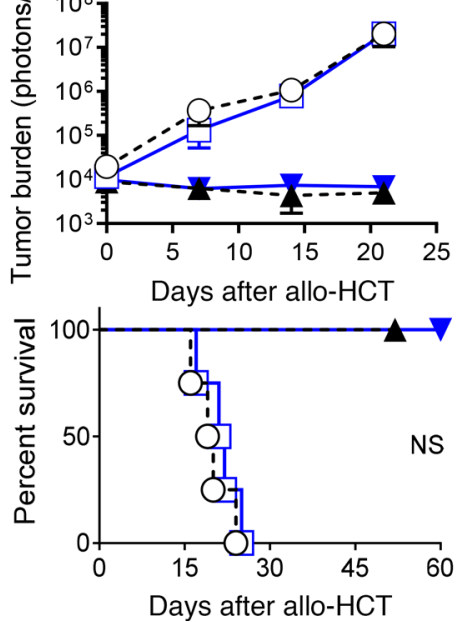

Day 14

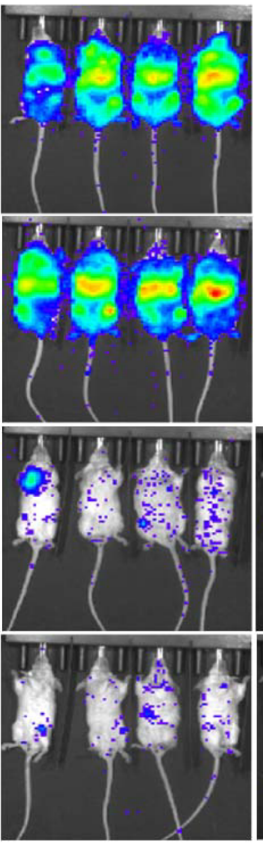

. O TCD-BM only + Saline

$\square$ TCD-BM only + Bambuterol

- $\mathrm{TCD}-\mathrm{BM}+\mathrm{T}$ cells + Saline

$\checkmark \mathrm{TCD}-\mathrm{BM}+\mathrm{T}$ cells + Bambuterol

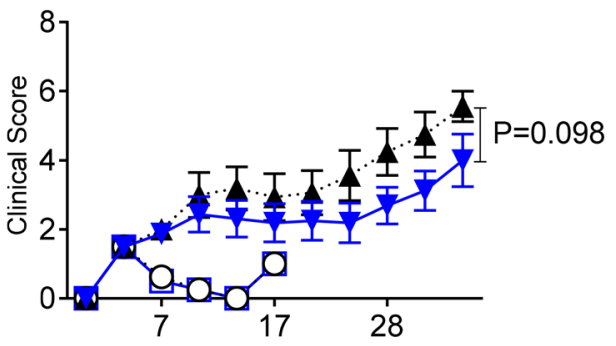

Days after allo-HCT

D

Saline
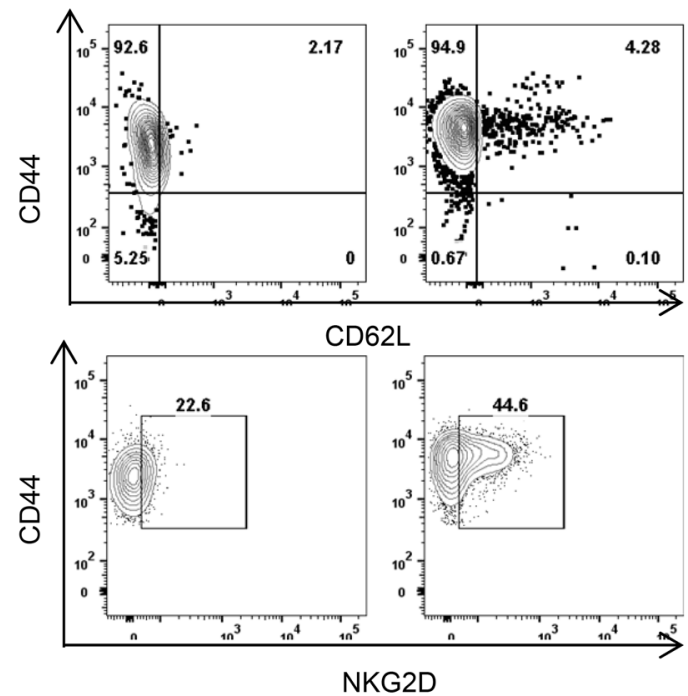

$\underline{\text { Day } 35}$

All mice deceased

(Tumor burden)

All mice deceased

(Tumor burden)

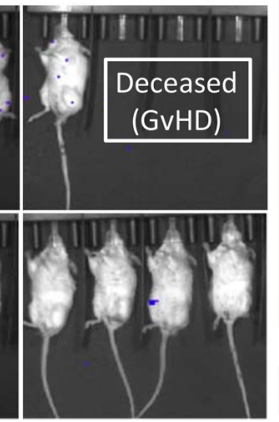

O. TCD-BM only + Saline

曰 TCD-BM only + Bambuterol

-A. TCD-BM + T cells + Saline

of $\forall$ TCD-BM + T cells + Bambuterol

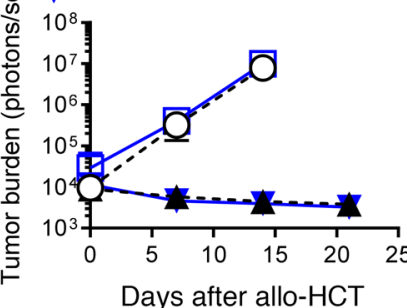

Days after allo-HCT
O TCD-BM only + Saline

$\square$ TCD-BM only + Bambuterol

-A. TCD-BM + T cells + Saline

$₹$ TCD-BM + T cells + Bambuterol

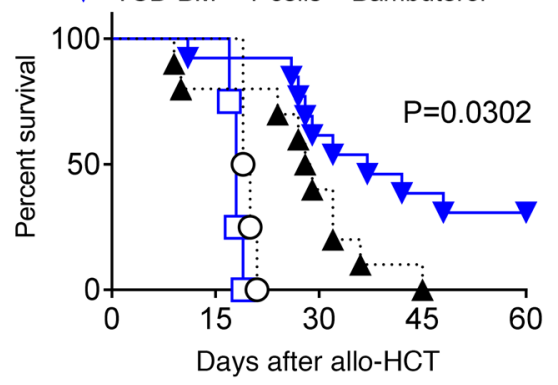

Days after allo-HCT
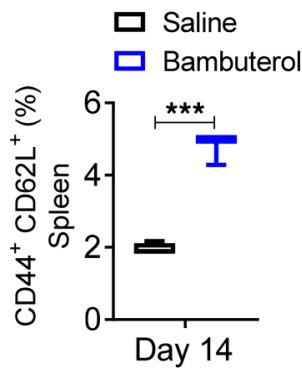

Daline

$\square$ Bambuterol

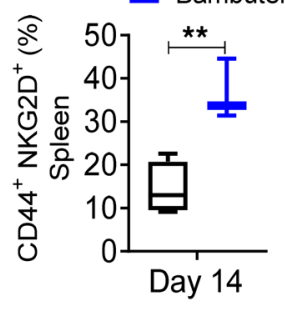

Figure 7. The selective $\mathbf{\beta 2}$-AR agonist bambuterol does not compromise the GvT effect. Experiments with A20 tumor cells expressing luciferase (A20 cells) were monitored by in vivo bioluminescent imaging (BLI). Recipients were i.v. injected with $1 \times 10^{5} \mathrm{~A} 20$ cells 4 hours before lethal irradiation, followed by MHC-mismatched allo-HCT with WT C57BL/6 TCD-BM with or without T cells purified from C57BL/6 WT spleens. All recipients received daily saline or bambuterol injections after transplant. (A and B) BALB/c mice received A20 cells followed by allo-HCT with BM alone or with $5 \times 10^{5} \mathrm{~T}$ cells. (C) BALB/C 
mice received A20 cells followed by allo-HCT with BM alone or with $2 \times 10^{5}$ T cells. Recipients of A20 cells and TCD-BM alone died before day 28 . Recipients of A20 cells, TCD-BM, and T cells displayed controlled tumor growth and improved survival, with improved GvHD severity when receiving bambuterol. Decreasing the donor T cells improved GVHD severity. Bambuterol treatment did not diminish the GVT effect. (D) BALB/c mice received A2O cells followed by allo-HCT with BM alone or with $5 \times 10^{5} \mathrm{~T}$ cells. CD44+NKC2D+ and CD62L ${ }^{+} \mathrm{CD} 44^{+}$in $\mathrm{CD} 4^{+} \mathrm{T}$ cell frequencies within splenic single live $\mathrm{H}-2^{\mathrm{b}+} \mathrm{H}-2^{\mathrm{d}-} \mathrm{CD} 45^{+} \mathrm{CD} 3^{+}$ cell populations on day 14 after transplant were increased with bambuterol treatment. Data were pooled from 2 individual experiments, each with $n=2-3$ per group to obtain total of $n=4-6$ per group. Log-rank (Mantel-Cox) test was used to compare survival curves between saline and bambuterol groups. For comparison of the means, an unpaired 2-tailed $t$ test was used in C. Two-way ANOVA with Tukey's multiple comparisons test was used for body weight, clinical score, and tumor burden difference in $\mathbf{A}$ and $\mathbf{B} .{ }^{*} P<0.05$ and ${ }^{* *} P<0.01$. Tumor burden, body weight, clinical score, and survival data are shown as means \pm SEM. Other data are presented as median \pm min to max.

skin, GI tract, and liver in murine and clinical allo-HCT (45-48). Furthermore, $\mathrm{CD} 4^{+} \mathrm{T}$ cells have been shown to be important in the development and severity of aGvHD, as donor $\mathrm{CD} 4^{+} \mathrm{T}$ cell depletion prevents aGvHD in mouse models (49).

Treg populations including natural Tregs (nTregs) and iTregs ameliorate GvHD severity by suppressing cytotoxic T cells $(15,19,50)$, and Treg deficiency after allo-HCT has been associated with severe aGvHD (51). Previous studies have shown that $\beta 2$-AR signaling induces Treg immunosuppressive functions through an increase in CTLA-4 expression and a decrease in IL-2 levels $(34,35)$. In this study, $\beta 2$-AR activation by bambuterol in $\mathrm{CD}^{+}$and $\mathrm{CD} 8^{+} \mathrm{T}$ cells led to enhanced development of Foxp- $3^{+}$Tregs and the inhibitory cytokine IL-10. Previous work found that preclinical iTreg therapy to control GvHD was unstable due to the loss of Foxp-3 expression $(52,53)$. In this study, bambuterol improved Foxp- $3^{+} \mathrm{CD} 4^{+} \mathrm{T}$ cell development 7 and 14 days after allo-HCT, demonstrating a stable effect on Foxp-3 expression. Furthermore, $\beta 2$-AR signaling resulted in decreased expression of T-bet, the main Th1 transcription factor, and the inflammatory cytokine IFN- $\gamma$, skewing the Th1/Th17:Treg/Th2 balance toward a Treg/Th2 phenotype. Treg/Th2 T cells have been shown to be protective against severe $\operatorname{aGvHD}(18,54,55)$. The generation of Foxp $-3^{+}$Tregs and the Treg/conventional T cell ratio are reduced during severe aGvHD $(56,57)$. Previous work has shown that $\beta 2$-AR signaling on Th1, Th17, and effector cells led to suppressed $\mathrm{T}$ cell proliferation (58). It could be postulated that the protective effects we observed could be due to a reduction in Th1 cells and not the result of augmented Treg reconstitution. However, using Treg-depleted $\mathrm{CD} 4^{+} \mathrm{T}$ cells as donor cells in vitro and in vivo, we demonstrate that the $\beta 2$-AR signaling effect on Th1 cells is independent of the effect on thymic Tregs. Thus, the mechanism of aGvHD amelioration through $\beta 2$-AR activation is likely a result of Th1/Th17 cytotoxic $\mathrm{T}$ cell suppression and enhanced Treg reconstitution.

Previous work has shown that $\beta 2$-AR activation by specific agonists causes $\beta 2$-AR recycling through PKA signaling $(59,60)$. PKA activation downstream of $\beta 2$-AR signaling inhibits rapid, unregulated bulk $\beta 2$-AR recycling and, instead, exclusively activates slow, but regulated, sequence-dependent recycling of $\beta 2$-AR $(59,61)$. This results in $\beta 2$-AR resensitization and functional $\beta 2$-AR expression on the cell surface $(59,62)$. These previously reported mechanistic studies support our premise, suggesting that treatment with a $\beta 2$-AR-specific agonist could skew T cell differentiation and suppress severe GvHD after allo-HCT. In this study, we have shown that $\mathrm{T}$ cell $\beta 2$-AR expression increased during allo-HCT in the spleen and liver and that bambuterol effectively increased the ratio of immunosuppressive cells to cytotoxic $\mathrm{T}$ cells. Thus, bambuterol induces $\beta 2$-AR recycling and resensitization rather than $\beta 2$-AR degradation.

While investigating the mechanisms of $\beta 2$-AR signaling during Treg differentiation, we found that GSK-3 undergoes rapid dephosphorylation after culturing $\mathrm{CD}^{+} \mathrm{T}$ cells in Treg media, and $\beta 2$-AR signaling accelerated this dephosphorylation. GSK-3 is a relatively unique kinase because it is primarily active only when dephosphorylated (40,63); thus, $\beta 2$-AR signaling accelerated GSK-3 activity and increased iTreg generation. GSK-3 interacts with many different substrates and is associated with differentiation of multiple cell types, including adipocytes, neurons, Th17, Th1, and stem cells (37, 64-67). However, G proteins recruit GSK-3 to the membrane, increasing kinase activity and preventing $\beta$-catenin degradation (68). Inhibition of GSK kinase activity attenuates the stabilization of Foxp-3 and the immunosuppressive functions of Tregs through Wnt/ $\beta$-catenin signaling $(36,69)$, suggesting that $\beta 2$-AR improves Treg generation through the GSK/Wnt signaling pathway.

In this report, high Foxp-3 levels in Tregs were significantly lessened when GSK-3 activity was inhibited. GSK-3 inhibition also prevented bambuterol treatment from further increasing Foxp-3 levels. GSK-3 activity was necessary throughout iTreg differentiation, as no inactive-phosphorylated GSK-3 was detected after 3 days of culturing naive $\mathrm{CD} 4^{+} \mathrm{T}$ cells in Treg media. The classical cAMP/PKA activity downstream of the $\beta 2$-AR exists in tumor cells as well as adipocytes, suppressing GSK-3 activity $(70,71)$. 
cAMP-independent $\beta 2$-AR activation increases the activity of GSK-3 $(39,72)$, implying that a cAMP-independent mechanism is responsible for $\beta 2$-AR/GSK-3/Foxp-3 pathway activation, leading to increased Treg development.

MDSCs are immunosuppressive cells that decrease aGvHD severity by inhibiting cytotoxic $\mathrm{T}$ cell function via arginase-1 (41). IL-13 is a key cytokine for the induction and maintenance of arginase-1 (73). $\beta 2-\mathrm{AR}$-mediated Th2/Treg differentiation may increase Th2 cytokines, including IL-13, indirectly increasing MDSC generation. MDSCs skew the Th1/Th2 balance toward Th2, preventing murine aGvHD (74), and MDSC-induced aGvHD prevention was seen in a humanized aGvHD model (41, $75)$. Previous studies demonstrated that $\beta 2$-AR activation increased the mobilization and accumulation of MDSCs. MDSCs generated by $\beta 2-\mathrm{AR}$ activation in the $\mathrm{BM}$ also may modulate tissue damage repair after allo-HCT, in addition to suppressing allogeneic cytotoxic T cells.

Bambuterol did not impair the GvT effect in the A20 lymphoma model. $\beta 2$-AR activation is associated with effector cell expression of NKG2D, which plays an important role in balancing GvT activity and $\operatorname{aGvHD}(43,44,76,77)$. In agreement with our data, a recent study has shown that systemic $\beta 2-A R$ activation significantly increases TCR- $\gamma \delta$ T cell antitumor effects via NKG2D (78). Future studies will be necessary to clarify the role of NKG2D and determine the dynamics of its expression in GvHD after bambuterol therapy. This is especially pertinent because it has been shown that NKG2D increases GvHD severity in the days immediately after allo-HCT yet becomes critical for maintaining GvT effects as time progresses (79). Additionally, it is also possible that $\beta 2$-AR signaling induces NKG2D expression on T cells indirectly via MDSCs, as it has been shown that adoptive transfer of MDSCs can increase the GvT effect by inducing effector cell upregulation of NKG2D while preventing severe aGvHD (44). If this is the case, T cell NKG2D expression may begin at least a week after allo-HCT, when MDSCs begin to find their way into affected tissues and, thus, have minimal effects on GvHD severity immediately after transplantation. Bambuterol also improved the generation of central memory cells and increased central memory cell frequency in the spleen, marked by $\mathrm{CD} 44^{+} \mathrm{CD} 62 \mathrm{~L}^{+}$cells in the $\mathrm{CD} 4^{+} \mathrm{T}$ cell population (Figure $7 \mathrm{D}$ ). $\mathrm{CD} 4^{+}$memory $\mathrm{T}$ cells mediate a strong GvT effect by recognizing recipient alloantigen on leukemia cells without causing aGvHD (80). T9 ${ }_{\text {IL-33 }}$ cells, a population of IL-9-producing T cells activated via the ST2/IL-33 pathway with an enhanced central memory phenotype, exhibit antitumor activity without inducing aGvHD (81).

In summary, $\beta 2$ agonist stimulation of $\beta 2$-ARs on donor $\mathrm{T}$ cells changes $\mathrm{T}$ cell differentiation from the Th1/Th17 phenotype toward the Th2/Treg phenotype and induces MDSC generation from BM cells. $\beta 2$-AR stimulation can control the severity and fatality of aGvHD without impairing the GvT response. These data support testing selective $\beta 2$-AR agonist therapeutic strategies for the prevention and treatment of aGvHD after allo-HCT.

\section{Methods}

Study design. This study was designed to activate T cell $\beta 2$-ARs, especially on CD $4^{+} \mathrm{T}$ cells. We hypothesized that this $\mathrm{CD}^{+} \mathrm{T}$ cell activation would result in a decreased population of cytotoxic $\mathrm{T}$ cells and an increased population of aGvHD-suppressive cells, including Tregs. We assessed the potential of a long-acting selective $\beta 2$-AR agonist, bambuterol (a terbutaline prodrug), in multiple experimental murine models of aGvHD. The long-acting $\beta 2$-AR agonist (using saline as a vehicle and a control) allowed for a decreased injection frequency. We evaluated the therapeutic effect of bambuterol on aGvHD severity by monitoring body weight, clinical and histopathological aGvHD scores, and recipient survival. We used a multiplex ELISA to measure the decrease in the plasma levels of the systemic proinflammatory cytokines IFN- $\gamma$ and IL-17, as well as the increase in systemic antiinflammatory cytokine production such as IL-10. We then investigated the role of the $\beta 2-\mathrm{AR}$ in $\mathrm{CD}^{+} \mathrm{T}$ cell differentiation and the phenotype of $\mathrm{CD}^{+}$and $\mathrm{CD} 8^{+} \mathrm{T}$ cells after allo-HCT. We further assessed other immunomodulatory effects of bambuterol. These included the generation of MDSCs from donor BM cells and the impact on GvT during allo-HCT. A luciferase-expressing A20 lymphoma cell line was used to assess the effects of bambuterol on GvT activity. We established a humanized mouse model of aGvHD using human PBMCs to study the effects of bambuterol on aGvHD. All in vitro and in vivo experiments were repeated independently in triplicate and duplicate, respectively.

Animals and tumor cells. C57BL/6J $\left(\mathrm{H}-2^{\mathrm{b}}\right), \mathrm{C} 3 \mathrm{H} / \mathrm{SW}\left(\mathrm{H}-2^{\mathrm{b}}\right)$, and BALB/cJ $\left(\mathrm{H}-2^{\mathrm{d}}\right)$ mice were purchased from the Jackson Laboratory. The $\beta 2-\mathrm{AR}-\mathrm{KO}\left(\beta 2 \mathrm{AR}^{-/-}\right) \mathrm{C} 57 \mathrm{BL} / 6 \mathrm{~J}$ mice were developed in the Roswell Park DLAR facility. Mice were maintained at Roswell Park IACUC-mandated ST $\left(\sim 22^{\circ} \mathrm{C}\right)$. The NSGHLA-A2 breeding pair mice were provided by Kunle Odunsi's lab (Center for Immunotherapy, Roswell Park 
Comprehensive Cancer Center, Buffalo, New York, USA). All in vivo experiments were performed according to Roswell Park animal care guidelines.

$B M$ transplantation for $G v T$ effect and $a G v H D$. For aGvHD studies, WT BALB/cJ $\left(\mathrm{H}-2^{\mathrm{d}}\right)$ or C3H/ SW $\left(\mathrm{H}-2^{\mathrm{b}}\right)$ were used as hosts and irradiated with a single fraction of 8.5 or 11 Gray (Gy), respectively, from a Cs-137 source. On day 0 , mice were injected i.v. with $3.5 \times 10^{6} \mathrm{TCD}-\mathrm{BM}$ cells only or combined with $0.7 \times 10^{6}$ pan-T cells isolated from WT or $\beta 2-\mathrm{AR}^{-/} \mathrm{C} 57 \mathrm{BL} / 6 \mathrm{~J}\left(\mathrm{H}-2^{\mathrm{b}}\right)$ mice $(\mathrm{B} 6 \rightarrow \mathrm{BALB} / \mathrm{c}$ model), $3.5 \times 10^{6} \mathrm{TCD}-\mathrm{BM}$ cells only, or combined with $1.5 \times 10^{6}$ pan-T cells isolated from WT or $\beta 2-\mathrm{AR}^{-/}$ $\mathrm{C} 57 \mathrm{BL} / 6 \mathrm{~J}\left(\mathrm{H}-2^{\mathrm{b}}\right)$ mice $(\mathrm{B} 6 \rightarrow \mathrm{C} 3 \mathrm{H} / \mathrm{SW}$ model). In some experiments, BALB/c mice were irradiated using $8.5 \mathrm{~Gy}$ and transplanted with $3.5 \times 10^{6} \mathrm{TCD}$-BM cells only or combined with either $0.2 \times 10^{6}$ $\mathrm{CD}^{+} \mathrm{T}$ cells or with $0.5 \times 10^{5} \mathrm{CD}^{+} \mathrm{CD} 25^{-} \mathrm{T}$ cells. Weights and aGvHD scores of host mice were recorded every 3 days and were monitored daily for survival. In the aGvHD humanized model, NSG mice were irradiated with $2.5 \mathrm{~Gy}$ and transplanted with $2 \times 10^{6}$ human PBMCs on day 0. For GvT studies, WT BALB/cJ hosts $\left(\mathrm{H}-2^{\mathrm{d}}\right)$ were irradiated with a single dose $(8.50 \mathrm{~Gy})$. On day 0 , hosts were injected i.v. with $3.5 \times 10^{6} \mathrm{TCD}-\mathrm{BM}$ cells only or combined with $0.5 \times 10^{6}$ pan-T cells or $0.2 \times 10^{6} \mathrm{~T}$ cells isolated from B6 $\left(\mathrm{H}-2^{\mathrm{b}}\right)$ WT mice. Host mice were injected i.v. with $0.1 \times 10^{6}$ luciferase-expressing A20 tumor cells (23) 4 hours before transplantation. Recipient mice were given daily i.p. saline or bambuterol (MilliporeSigma, $1 \mathrm{mg} / \mathrm{kg}$ ) injections. Tumor burdens were measured by bioluminescence imaging weekly; tumor mortality and survival were monitored daily.

Reagents. Mice received $200 \mu \mathrm{L}$ bambuterol hydrochloride (B8684, MilliporeSigma), the prodrug for terbutaline at a dose of $1 \mathrm{mg} / \mathrm{kg}$ via i.p. injection. Control mice received $200 \mu \mathrm{L}$ saline. All recipients started daily i.p. injections on the day of allo-HCT, continuing for 30 days. For in vitro studies, terbutaline (T2528, MilliporeSigma) and propranolol (P0884, MilliporeSigma) were used at a $10 \mu \mathrm{M}$ concentration. The GSK-3 inhibitor SB216763 (S3442, MilliporeSigma) was used at a $1 \mu \mathrm{M}$ concentration.

Donor cell preparation. Donor BM cells were isolated from B6 WT or $\beta 2-\mathrm{AR}^{-/-}$mice. TCD-BM was performed using anti-CD90.2 microbeads (130-121-278, Miltenyi Biotec; purity > 92\%). Donor pan-T cells were purified from the spleens of $\mathrm{B} 6 \mathrm{WT}$ or $\beta 2-\mathrm{AR}^{-/-}$using mouse pan-T cell isolation kits (130-095-30, Miltenyi Biotec) (purity $>93 \%$ ). CD4 ${ }^{+} \mathrm{T}$ cells and $\mathrm{CD} 4^{+} \mathrm{CD} 25^{-} \mathrm{T}$ cells were purified using a pan-T cell isolation kit plus $\mathrm{CD}^{+}$biotin (53-6.7, BioLegend) or $\mathrm{CD}^{+}$biotin plus $\mathrm{CD} 25^{+}$biotin (7D4, eBioscience) antibodies, respectively (purity $>90 \%$ ).

Flow cytometric analysis. All antibodies and reagents for flow cytometry were listed in Supplemental Table 2. The cells were preincubated with purified anti-mouse CD16/CD32 mAb (2.4G2, BD Pharmingen) for 10 minutes at $4^{\circ} \mathrm{C}$ to prevent nonspecific antibody binding. The sample was then incubated with surface staining antibodies for 30 minutes at $4^{\circ} \mathrm{C}$. Fixable viability dye was used to distinguish live from dead cells. Intracellular transcription factor and cytokine staining was performed using the FoxP3/Transcription Factor Staining Buffer Set and the Fixation and Permeabilization Kit (00-5523-00, Thermo Fisher Scientific). For cytokine staining, cells were restimulated with phorbol myristate acetate (PMA; $50 \mathrm{ng} / \mathrm{mL})$, ionomycin (1 $\mu \mathrm{g} / \mathrm{mL}$; 407952, MilliporeSigma), and brefeldin-A (420601, BioLegend) for 4-5 hours before any staining. CD90.2 microbeads and pan-T cell isolation kits were purchased from Miltenyi Biotec.

Luminex immunoassay. Plasma was collected by retro-orbital bleeding on days 7 and 14 following transplant. Blood sample vials were placed on ice until all samples had been collected. After the final sample collection, vials were incubated at room temperature for 20 minutes to coagulate. Sample vials were centrifuged at $4^{\circ} \mathrm{C}$ for 20 minutes at $300 \mathrm{~g}$. Serum plasma was collected and frozen at $-80^{\circ} \mathrm{C}$. Mouse cytokine and chemokine 11-plex (MilliporeSigma) was performed by the Roswell Park Flow and Image Cytometry, Luminex Division, per the manufacturer's instructions.

Cell sorting. At day 14 after allo-HCT, $\mathrm{CD} 4^{+} \mathrm{T}$ cells (live- $\mathrm{H}-2^{\mathrm{b}+} \mathrm{CD} 45^{+} \mathrm{CD} 3^{+}$) were sorted from single-cell suspensions of the spleens from treated $\mathrm{BALB} / \mathrm{c}$ recipient mice for gene expression (Immunology Panel, NanoString) using BD FACSAria (BD Biosciences) in the Roswell Park Flow Cytometry Core Facility.

NanoString gene expression profiling analysis. Recipient splenic $\mathrm{CD} 4^{+} \mathrm{T}$ cells from $\mathrm{WT}$ or $\beta 2-\mathrm{AR}^{-/-}$donors were sorted, counted, and lysed in RLT buffer (79216, QIAGEN) on ice. The total CD4+ T cells after sorting ranged between $0.5 \times 10^{6}$ and $1 \times 10^{6}$ cells. Cells were immediately frozen in liquid nitrogen and then stored at $-80^{\circ} \mathrm{C}$ or in dry ice. Samples were sent to the Roswell Park Genomic Shared Resource for gene expression profiling. NanoString analysis was performed with the nCounter Analysis System at NanoString Technologies. The nCounter Mouse Immunology Kit, including 561 immunology-related mouse genes, was used in the study. 
Clinical aGvHD scoring criteria. The clinical aGvHD manifestations measured and observed included weight loss, change in posture, activity, fur texture, hair loss, and diarrhea. A modified scoring system (Supplemental Table 1) was used for aGvHD scoring (82).

$T$ cell differentiation. Total $\mathrm{CD}^{+} \mathrm{T}$ cells were purified from $\mathrm{B} 6$ spleens with magnetic isolation beads (Miltenyi Biotec). These cells were cultured at a concentration of $1 \times 10^{6}$ cells $/ \mathrm{mL}$ in TexMACS medium (130-197-196, Miltenyi Biotec) supplemented with 10\% FBS (35-011-CV, Corning), 1\% penicillin/streptomycin (30-002-CI, Corning), and 1\% L-glutamine (24-0050CI, Corning). T cells were cultured in Treg media including TexMACS medium (Miltenyi Biotec) supplemented with 10\% FBS, 1\% penicillin/streptomycin, $1 \%$ glutamine plus TGF- $\beta$ ( 5 ng/mL; 763102, BioLegend), IL-2 (20 ng/mL; 575402, BioLegend), and anti-CD28/CD3 microbeads (bead/cell ratio 1:1; T cell activation kit; 130-093-627, Miltenyi Biotec). $\mathrm{CD}^{+} \mathrm{T}$ cells were polarized toward Th1 cells using IL-2 $(20 \mathrm{ng} / \mathrm{mL})$ and IL-12 $(20 \mathrm{ng} / \mathrm{mL} ; 577002$, BioLegend) in TexMACS medium (Miltenyi Biotec) supplemented with 10\% FBS, 1\% penicillin/streptomycin, and $1 \%$ glutamine plus CD28/CD3 microbeads (Th1 media).

Histopathology scoring. At 14 days after allo-HCT, BALB/c host mice transplanted with B6 TCD-BM plus either WT or $\beta 2-\mathrm{AR}^{-/}$pan-T cells were sacrificed; large and small intestines were harvested, fixed in formalin, sectioned, and stained with $\mathrm{H} \& \mathrm{E}$. The intestinal tissue was examined using an established semiquantitative scoring system in a deidentified manner. Representative pictures were captured at total magnification of $100 \times$.

Western blot analysis. CD4 ${ }^{+} \mathrm{T}$ cells were sorted from the spleens of healthy B6 mice, cultured in Treg media plus CD3/C28 microbeads (Miltenyi Biotec). Cultured cells were treated with either $10 \mu \mathrm{M}$ terbutaline (MilliporeSigma, T2528) or $10 \mu \mathrm{M}$ terbutaline plus $1 \mu \mathrm{M}$ propranolol (MilliporeSigma, P0884) for 20, 60 , or 120 minutes and 1,2 , or 3 days. Cells were collected, washed in PBS, and frozen at $-80^{\circ} \mathrm{C}$. A radioimmunoprecipitation assay (RIPA) lysis buffer (Thermo Fisher Scientific, 8990) combined with Protease/ Phosphatase Inhibitor Mini Tablets (Pierce, A32959), and phenylmethanesulfonyl fluoride (MilliporeSigma, 36978) was then used to create lysate material for analysis. Protein concentrations were determined by BCA assay (Pierce, 23227). Samples were mixed with $4 \times$ Laemmli Sample Buffer (Bio-Rad, 1610747), heated to $95^{\circ} \mathrm{C}$ for 5 minutes, and loaded into wells of 4\%-20\% Mini-PROTEAN TGX Precast Protein Gels (Bio-Rad, 4561094) to separate proteins in Tris/Glycine/SDS running buffer (Bio-Rad, 1610732). The separated protein gels were transferred to a polyvinylidene difluoride membrane (MilliporeSigma) in Tris/Glycine transfer buffer (Bio-Rad, 1610734). Blots were blocked with 5\% BSA in TBS-T for 1 hour at room temperature. Primary antibody incubation took place overnight at $4^{\circ} \mathrm{C}$ in $5 \% \mathrm{BSA}$, and the antibodies used were rabbit anti-GSK-3 $\alpha / \beta$ (Cell Signaling Technology, 5676) and rabbit anti-phospho-GSK-3 $\alpha / \beta$ (Cell Signaling Technology, 8566). An anti-rabbit IgG, HRP-linked antibody (Cell Signaling Technology, 7074) was used to detect the presence of primary antibodies. Chemiluminescence from blots was detected after exposure to Clarity Western ECL Substrate (Bio-Rad, 1705060) by the Odyssey Fc imager (LI-COR).

$H R$ and BP measurements. The CODA 8 noninvasive BP acquisition system for mice (Kent Scientific) was used for all tail-cuff measurements. This device measures volume changes in mouse tail vessels via a volume pressure recording (VPR) cuff. The mice were acclimated in a designated quiet area $\left(22^{\circ} \mathrm{C} \pm 2{ }^{\circ} \mathrm{C}\right)$, ambulated into restraint tubes that were tightened to prevent excessive movement. The occlusion cuff was placed proximal and VPR cuff was placed distal on each tail. The mice were warmed with heating pads preheated between $33^{\circ} \mathrm{C}$ and $35^{\circ} \mathrm{C}$ for 5 minutes before and during $\mathrm{BP}$ recordings. To measure $\mathrm{BP}$, the occlusion cuff is inflated to $250 \mathrm{mmHg}$. During cuff deflation, the VPR cuff measures the blood volume as it returns to the tail vessels. Each recording session consisted of 15-25 inflation and deflation cycles, including 5 acclimation cycles not included in the analysis. HR and BP were measured at days 21 and 28 after allo-HCT in lethally irradiated BALB/c mice transplanted with TCD-BM with or without pan-T cells being treated with saline or bambuterol.

Data and materials availability. All data associated with this study are presented in the paper and/ or Supplemental Table 1.

Statistics. The tumor burden, body weight, and clinical score data are presented as mean \pm SEM. Other data are presented as median \pm minimum to maximum ( $\min$ to max). Differences between groups were analyzed using the unpaired 2-tailed Student's $t$ test and 1-way ANOVA for 2 and more than 2 groups, respectively. Animal survival (Kaplan-Meier survival curves) was analyzed by log-rank test. The body weight and clinical score difference was analyzed using 2-way ANOVA and presented by each time point. Multiple comparisons were assessed using Tukey's multiple comparison test. $P<0.05$ was considered statistically significant. All statistical analyses were performed by using GraphPad Prism v7. 
Study approval. All animal studies were reviewed and approved by the Roswell Park institutional animal care and use program and facilities (protocols 1140M and 1143M). All aspects of animal research and husbandry were conducted in accordance with the federal Animal Welfare Act and the NIH's Guide for the Care and Use of Laboratory Animals (National Academies Press, 2011.

\section{Author contributions}

HM initiated and HM, EAR, and PLM designed the study with input from BRB. HM performed the experiments with assistance from JLS, CRM, GLC, and UCS. JQ read the deidentified pathology slides. HM, $\mathrm{XC}, \mathrm{MMH}, \mathrm{TEH}, \mathrm{BRB}, \mathrm{EAR}$, and PLM analyzed and interpreted the data and wrote the paper.

\section{Acknowledgments}

The authors thank Bonnie L. Hylander, Jeanne M. Prendergast, Samuel A. Ministero, Minhui Chen, and Guanxi Qiao for technical assistance and support, as well as the Genomics Shared Resource (Roswell Park), Translational Imaging Shared Resource, and the Roswell Park Flow Cytometry Core Facility for expert support. This project was supported by NIH (NIH) grants R01 CA205246 and R01 CA236390 (to ER); R37 AI34495, R01 HL118979, and R01 HL56067 (to BRB); F32 CA239356 (to HM); the Roswell Park Alliance Foundation and a donation from Brendan and Elise McCarthy (PM); and NCI grant P30CA016056.

Address correspondence to: Elizabeth A. Repasky or Philip L. McCarthy, Roswell Park Comprehensive Cancer Center, Elm and Carlton Streets, Buffalo, New York 14263, USA. Email: elizabeth. repasky@roswellpark.org (E.A. Repasky), Philip.McCarthy@RoswellPark.org (P.L. McCarthy).

1. Jenq RR, van den Brink MR. Allogeneic haematopoietic stem cell transplantation: individualized stem cell and immune therapy of cancer. Nat Rev Cancer. 2010;10 (3):213-221.

2. Koyama M, Hill GR. Alloantigen presentation and graft-versus-host disease: fuel for the fire. Blood. $2016 ; 127$ (24):2963-2970.

3. Zeiser R, Blazar BR. Pathophysiology of Chronic Graft-versus-Host Disease and Therapeutic Targets. N Engl J Med. 2017;377 (26):2565-2579.

4. Zeiser R, Blazar BR. Acute Graft-versus-Host Disease - Biologic Process, Prevention, and Therapy. NEngl J Med. $2017 ; 377$ (22):2167-2179

5. Choi SW, Reddy P. Current and emerging strategies for the prevention of graft-versus-host disease. Nat Rev Clin Oncol. 2014;11 (9):536-547.

6. Ferrara JL, Levine JE, Reddy P, Holler E. Graft-versus-host disease. Lancet. 2009;373 (9674):1550-1561.

7. Shlomchik WD. Graft-versus-host disease. Nat Rev Immunol. 2007; 7 (5):340-352.

8. Perkey E, Maillard I. New Insights into Graft-Versus-Host Disease and Graft Rejection. Annu Rev Pathol. 2018;13:219-245.

9. Ratajczak P, et al. Th17/Treg ratio in human graft-versus-host disease. Blood. 2010;116 (7):1165-1171.

10. Coghill JM, Sarantopoulos S, Moran TP, Murphy WJ, Blazar BR, Serody JS. Effector CD4+ T cells, the cytokines they generate, and GVHD: something old and something new. Blood. 2011;117 (12):3268-3276.

11. Serody JS, Hill GR. The IL-17 differentiation pathway and its role in transplant outcome. Biol Blood Marrow Transplant. 2012;18 (1 Suppl):S56-S61.

12. Broady R, et al. Cutaneous GVHD is associated with the expansion of tissue-localized Th1 and not Th17 cells. Blood. 2010;116 (25):5748-5751.

13. Fulton LM, et al. Attenuation of acute graft-versus-host disease in the absence of the transcription factor ROR $\gamma$ t. $J$ Immunol. 2012;189 (4):1765-1772.

14. Carlson MJ, West ML, Coghill JM, Panoskaltsis-Mortari A, Blazar BR, Serody JS. In vitro-differentiated TH17 cells mediate lethal acute graft-versus-host disease with severe cutaneous and pulmonary pathologic manifestations. Blood. 2009;113 (6):1365-1374.

15. Beres AJ, Drobyski WR. The role of regulatory T cells in the biology of graft versus host disease. Front Immunol. 2013;4:163.

16. Elias S, Rudensky AY. Therapeutic use of regulatory T cells for graft-versus-host disease. Br J Haematol. $2019 ; 187$ (1):25-38.

17. Zaini RG, Al-Rehaili AA. The Therapeutic Strategies of Regulatory T Cells in Malignancies and Stem Cell Transplantations. J Oncol. 2019;2019:5981054.

18. Blazar BR, MacDonald KPA, Hill GR. Immune regulatory cell infusion for graft-versus-host disease prevention and therapy. Blood. 2018;131 (24):2651-2660.

19. Heinrichs J, Bastian D, Veerapathran A, Anasetti C, Betts B, Yu XZ. Regulatory T-Cell Therapy for Graft-versus-host Disease. J Immunol Res Ther. 2016;1 (1):1-14.

20. Matthews K, et al. Imbalance of effector and regulatory CD4 T cells is associated with graft-versus-host disease after hematopoietic stem cell transplantation using a reduced intensity conditioning regimen and alemtuzumab. Haematologica. $2009 ; 94$ (7):956-966.

21. Kokolus KM, et al. Baseline tumor growth and immune control in laboratory mice are significantly influenced by subthermoneutral housing temperature. Proc Natl Acad Sci USA. 2013;110 (50):20176-20181.

22. Leigh ND, et al. Housing Temperature-Induced Stress Is Suppressing Murine Graft-versus-Host Disease through $\beta 2$-Adrenergic Receptor Signaling. J Immunol. 2015;195 (10):5045-5054.

23. Mohammadpour H, O’Neil R, Qiu J, McCarthy PL, Repasky EA, Cao X. Blockade of Host $\beta 2$-Adrenergic Receptor Enhances 
Graft-versus-Tumor Effect through Modulating APCs. J Immunol. 2018;200 (7):2479-2488.

24. Strosberg AD. Structure, function, and regulation of adrenergic receptors. Protein Sci. 1993;2 (8):1198-1209.

25. Wachter SB, Gilbert EM. Beta-adrenergic receptors, from their discovery and characterization through their manipulation to beneficial clinical application. Cardiology. 2012;122 (2):104-112.

26. Mohammadpour $\mathrm{H}$, et al. $\beta 2$ adrenergic receptor-mediated signaling regulates the immunosuppressive potential of myeloid-derived suppressor cells. J Clin Invest. 2019;129 (12):5537-5552.

27. Qiao G, Chen M, Bucsek MJ, Repasky EA, Hylander BL. Adrenergic Signaling: A Targetable Checkpoint Limiting Development of the Antitumor Immune Response. Front Immunol. 2018;9:164.

28. Qiao $\mathrm{G}$, et al. $\beta$-Adrenergic signaling blocks murine $\mathrm{CD} 8^{+} \mathrm{T}$-cell metabolic reprogramming during activation: a mechanism for immunosuppression by adrenergic stress. Cancer Immunol Immunother. 2019;68 (1):11-22.

29. Eng JW, Kokolus KM, Reed CB, Hylander BL, Ma WW, Repasky EA. A nervous tumor microenvironment: the impact of adrenergic stress on cancer cells, immunosuppression, and immunotherapeutic response. Cancer Immunol Immunother. 2014;63 (11):1115-1128.

30. Vasamsetti SB, et al. Sympathetic Neuronal Activation Triggers Myeloid Progenitor Proliferation and Differentiation. Immunity. 2018;49 (1):93-106.e7

31. Sanders VM. The beta2-adrenergic receptor on T and B lymphocytes: do we understand it yet? Brain Behav Immun. 2012;26 (2):195-200.

32. Kohm AP, Mozaffarian A, Sanders VM. B cell receptor- and beta 2-adrenergic receptor-induced regulation of B7-2 (CD86) expression in B cells. J Immunol. 2002;168 (12):6314-6322.

33. Nissen MD, Sloan EK, Mattarollo SR. $\beta$-Adrenergic Signaling Impairs Antitumor CD8 $8^{+}$T-cell Responses to B-cell Lymphoma Immunotherapy. Cancer Immunol Res. 2018;6 (1):98-109.

34. Guereschi MG, et al. Beta2-adrenergic receptor signaling in CD4+ Foxp3+ regulatory T cells enhances their suppressive function in a PKA-dependent manner. Eur J Immunol. 2013;43 (4):1001-1012.

35. Dugger KJ, Chrisman T, Sayner SL, Chastain P, Watson K, Estes R. Beta-2 adrenergic receptors increase TREG cell suppression in an OVA-induced allergic asthma mouse model when mice are moderate aerobically exercised. BMC Immunol. $2018 ; 19$ (1):9.

36. Amphiregulin Confers Regulatory T Cell Suppressive Function and Tumor Invasion via the EGFR/GSK-3 $\beta / F o x p 3$ Axis J Biol Chem. 2016;291(40):21085-21095.

37. Beurel E, et al. Regulation of Th1 cells and experimental autoimmune encephalomyelitis by glycogen synthase kinase-3. J Immunol. 2013;190 (10):5000-5011.

38. Jope RS, Johnson GV. The glamour and gloom of glycogen synthase kinase-3. Trends Biochem Sci. 2004;29 (2):95-102.

39. Zhou J, et al. GSK-3alpha directly regulates beta-adrenergic signaling and the response of the heart to hemodynamic stress in mice. J Clin Invest. 2010;120 (7):2280-2291.

40. Beurel E, Grieco SF, Jope RS. Glycogen synthase kinase-3 (GSK3): regulation, actions, and diseases. Pharmacol Ther. 2015;148:114-131.

41. Koehn BH, Blazar BR. Role of myeloid-derived suppressor cells in allogeneic hematopoietic cell transplantation. J Leukoc Biol. 2017;102 (2):335-341

42. Negrin RS. Graft-versus-host disease versus graft-versus-leukemia. Hematology Am Soc Hematol Educ Program. 2015;2015:225-230.

43. Carapito R, Aouadi I, Ilias W, Bahram S. Natural Killer Group 2, Member D/NKG2D Ligands in Hematopoietic Cell Transplantation. Front Immunol. 2017;8:368.

44. Zhang J, et al. The mechanistic study behind suppression of GVHD while retaining GVL activities by myeloid-derived suppressor cells. Leukemia. 2019;33 (8):2078-2089.

45. Kappel LW, et al. IL-17 contributes to CD4-mediated graft-versus-host disease. Blood. 2009;113 (4):945-952.

46. Radojcic V, et al. STAT3 signaling in CD4+ T cells is critical for the pathogenesis of chronic sclerodermatous graft-versus-host disease in a murine model. J Immunol. 2010;184 (2):764-774.

47. Zhao K, et al. Dynamic regulation of effector IFN- $\gamma$-producing and IL-17-producing T cell subsets in the development of acute graft-versus-host disease. Mol Med Rep. 2016;13 (2):1395-1403.

48. Fowler DH. Th1/Th2 and Tc1/Tc2 cells: Experimental Models and Clinical Translation. In: Socie G, Zeiser R, Blazar BR, eds. Immune Biology of Allogeneic Hematopoietic Stem Cell Transplantation. Cambridge, MA;Elsevier; 2019:195-209.

49. Ni X, et al. PD-L1 interacts with CD80 to regulate graft-versus-leukemia activity of donor CD8+ T cells. J Clin Invest. 2017;127 (5):1960-1977.

50. Riegel C, Boeld TJ, Doser K, Huber E, Hoffmann P, Edinger M. Efficient treatment of murine acute GvHD by in vitro expanded donor regulatory T cells. Leukemia. 2020;34 (3):895-908.

51. Rezvani K, et al. High donor FOXP3-positive regulatory T-cell (Treg) content is associated with a low risk of GVHD following HLA-matched allogeneic SCT. Blood. 2006;108 (4):1291-1297.

52. Beres A, Komorowski R, Mihara M, Drobyski WR. Instability of Foxp3 expression limits the ability of induced regulatory T cells to mitigate graft versus host disease. Clin Cancer Res. 2011;17 (12):3969-3983.

53. Zhang $\mathrm{P}$, et al. Induced regulatory $\mathrm{T}$ cells promote tolerance when stabilized by rapamycin and IL-2 in vivo. J Immunol. 2013;191 (10):5291-5303.

54. Belle L, et al. Blockade of interleukin-27 signaling reduces GVHD in mice by augmenting Treg reconstitution and stabilizing Foxp3 expression. Blood. 2016;128 (16):2068-2082.

55. Di Ianni M, et al. Tregs prevent GVHD and promote immune reconstitution in HLA-haploidentical transplantation. Blood. 2011;117 (14):3921-3928.

56. Edinger M, et al. CD4+CD25+ regulatory T cells preserve graft-versus-tumor activity while inhibiting graft-versus-host disease after bone marrow transplantation. Nat Med. 2003;9 (9):1144-1150.

57. Zorn E, et al. Reduced frequency of FOXP3 + CD4+CD25+ regulatory T cells in patients with chronic graft-versus-host disease. Blood. 2005;106 (8):2903-2911.

58. Bucsek MJ, Giridharan T, MacDonald CR, Hylander BL, Repasky EA. An overview of the role of sympathetic regulation of immune responses in infectious disease and autoimmunity. Int J Hyperthermia. 2018;34 (2):135-143. 
59. Vistein R, Puthenveedu MA. Reprogramming of G protein-coupled receptor recycling and signaling by a kinase switch. Proc Natl Acad Sci USA. 2013;110 (38):15289-15294

60. Jean-Alphonse F, Bowersox S, Chen S, Beard G, Puthenveedu MA, Hanyaloglu AC. Spatially restricted G protein-coupled receptor activity via divergent endocytic compartments. J Biol Chem. 2014;289 (7):3960-3977.

61. Vistein R, Puthenveedu MA. Src regulates sequence-dependent beta-2 adrenergic receptor recycling via cortactin phosphorylation. Traffic. 2014;15 (11):1195-1205.

62. Millman EE, et al. Rapid recycling of beta-adrenergic receptors is dependent on the actin cytoskeleton and myosin Vb. Traffic. 2008;9 (11):1958-1971.

63. Stambolic V, Woodgett JR. Mitogen inactivation of glycogen synthase kinase-3 beta in intact cells via serine 9 phosphorylation. Biochem J. 1994;303 (Pt 3):701-704.

64. Cole AR. GSK3 as a Sensor Determining Cell Fate in the Brain. Front Mol Neurosci. 2012;5:4.

65. Beurel E. Regulation of inflammation and T cells by glycogen synthase kinase-3: links to mood disorders. Neuroimmunomodulation. 2014;21 (2-3):140-144.

66. Beurel E, Yeh WI, Michalek SM, Harrington LE, Jope RS. Glycogen synthase kinase-3 is an early determinant in the differentiation of pathogenic Th17 cells. J Immunol. 2011;186 (3):1391-1398.

67. Saraswati AP, Ali Hussaini SM, Krishna NH, Babu BN, Kamal A. Glycogen synthase kinase-3 and its inhibitors: Potential target for various therapeutic conditions. Eur J Med Chem. 2018;144:843-858.

68. Jernigan KK, et al. Gbetagamma activates GSK3 to promote LRP6-mediated beta-catenin transcriptional activity. Sci Signal 2010;3 (121):ra37.

69. Graham JA, et al. Suppressive regulatory T cell activity is potentiated by glycogen synthase kinase 3 \{beta\} inhibition. $J$ Biol Chem. 2010;285 (43):32852-32859.

70. Fang X, Yu SX, Lu Y, Bast RC, Woodgett JR, Mills GB. Phosphorylation and inactivation of glycogen synthase kinase 3 by protein kinase A. Proc Natl Acad Sci USA. 2000;97 (22):11960-11965.

71. Markussen LK, Winther S, Wicksteed B, Hansen JB. GSK3 is a negative regulator of the thermogenic program in brown adipocytes. Sci Rep. 2018;8 (1):3469

72. Morioka N, Sugimoto T, Tokuhara M, Dohi T, Nakata Y. Noradrenaline induces clock gene Per1 mRNA expression in C6 glioma cells through beta (2)-adrenergic receptor coupled with protein kinase A - cAMP response element binding protein (PKACREB) and Src-tyrosine kinase - glycogen synthase kinase-3beta (Src-GSK-3beta). J Pharmacol Sci. 2010;113 (3):234-245.

73. Highfill SL, et al. Bone marrow myeloid-derived suppressor cells (MDSCs) inhibit graft-versus-host disease (GVHD) via an arginase-1-dependent mechanism that is up-regulated by interleukin-13. Blood. 2010;116 (25):5738-5747.

74. Messmann JJ, Reisser T, Leithäuser F, Lutz MB, Debatin KM, Strauss G. In vitro-generated MDSCs prevent murine GVHD by inducing type $2 \mathrm{~T}$ cells without disabling antitumor cytotoxicity. Blood. 2015;126 (9):1138-1148.

75. Wang K, et al. Early myeloid-derived suppressor cells (HLA-DR ${ }^{-/{ }^{l o w}} \mathrm{CD} 33^{+} \mathrm{CD} 16^{-}$) expanded by granulocyte colony-stimulating factor prevent acute graft-versus-host disease (GVHD) in humanized mouse and might contribute to lower GVHD in patients post allo-HSCT. J Hematol Oncol. 2019;12 (1):31.

76. Nishimura R, et al. In vivo trafficking and survival of cytokine-induced killer cells resulting in minimal GVHD with retention of antitumor activity. Blood. 2008;112 (6):2563-2574.

77. Laport GG, et al. Adoptive immunotherapy with cytokine-induced killer cells for patients with relapsed hematologic malignancies after allogeneic hematopoietic cell transplantation. Biol Blood Marrow Transplant. 2011;17 (11):1679-1687.

78. Baker FL, et al. Systemic $\beta$-Adrenergic Receptor Activation Augments the ex vivo Expansion and Anti-Tumor Activity of V $\gamma 9$ V 82 T-Cells. Front Immunol. 2019;10:3082.

79. Karimi MA, et al. NKG2D expression by CD8+ T cells contributes to GVHD and GVT effects in a murine model of allogeneic HSCT. Blood. 2015;125 (23):3655-3663.

80. Zheng H, et al. Effector memory CD4+ T cells mediate graft-versus-leukemia without inducing graft-versus-host disease. Blood. 2008;111 (4):2476-2484

81. Ramadan A, et al. Specifically differentiated T cell subset promotes tumor immunity over fatal immunity. J Exp Med. 2017;214 (12):3577-3596

82. Tugues S, et al. Graft-versus-host disease, but not graft-versus-leukemia immunity, is mediated by GM-CSF-licensed myeloid cells. Sci Transl Med. 2018;10 (469):eaat8410. 